\title{
Responses of European anchovy vital rates and population growth to environmental fluctuations: An individual-based modeling approach
}

\author{
H. Pethybridge ${ }^{a, *}$, D. Roos ${ }^{b}$, V. Loizeau ${ }^{a}$, L. Pecquerie ${ }^{c}$, C. Bacher ${ }^{a}$
}

\author{
a IFREMER, Research Unit: Biogeochemistry and Ecotoxicology, Centre de Brest, 29280 Plouzané, France \\ ${ }^{\mathrm{b}}$ IFREMER, Research Unit: Fisheries Resources, Centre de Séte, France \\ c University of California Santa Barbara, Department of Ecology, Evolution and Marine Biology, Santa Barbara, \\ CA 93106-9620, USA
}

*: Corresponding author : Heidi Pethybridge, Tel.: +33 298224363 ; email addresses :

Heidi.Pethybridge@ifremer.fr ; heidp@utas.edu.au

\begin{abstract}
:
A size-structured, bioenergetics model was implemented to examine the effects of short-term environmental changes on European anchovy, Engraulis encrasicolus, in the North-western Mediterranean Sea. The model approach was based on Dynamic Energy Budget (DEB) theory and details the acquisition and allocation of energy $\left(\mathrm{J} \mathrm{d}^{-1}\right)$ during an organisms' full life-cycle. Model calibration was achieved using biometric data collected from the Gulf of Lions between 2002 and 2011. Bioenergetics simulations successfully captured ontogenetic and seasonal growth patterns, including active growth in spring/summer, loss of mass in autumn/winter and the timing and amplitude of multi-batch spawning events. Scenario analysis determined that vital rates (growth and fecundity) were highly sensitive to short-term environmental changes. The DEB model provided a robust foundation for the implementation of an individual-based population model (IBM) in which we used to test the responses of intrinsic and density-independent population growth rates $(r)$ to observed and projected environmental variability. IBM projections estimate that $r$ could be reduced by as much as $15 \%$ (relative to that estimated under mean conditions) due to either a $5 \%\left(0.8{ }^{\circ} \mathrm{C}\right)$ drop in temperature (due to a reduced spawning duration), a $18 \%$ (25 $\mathrm{mg}$ zooplankton $\mathrm{m}^{-3}$ ) depletion in food supply, a $30 \%$ increase in egg mortality rates, or with the phytoplankton bloom peaking 5 weeks earlier (in late-February/Winter). The sensitivity of $r$ to short-term (1 year) and long-term (4-10 year) environmental changes were similar, highlighting the importance of first-year spawners. In its current form, the models presented here could be incorporated into spatially-explicit, higher-trophic (predatorprey and end-to-end ecosystem), larval-dispersal and toxicokinetic models or adapted to other shortlived foraging fish (clupeid) species.
\end{abstract}

\section{Highlights}

IBM implemented for European anchovy, an important ecological and economical species. Mean ontogenetic and seasonal growth and fecundity patterns were accurately captured. High variation in anchovy vital rates can be explained by the model. Population growth rate $(r)$ sensitivity to climate scenarios are quantified. A $0.8^{\circ} \mathrm{C}$ drop in temperature could cause a $15 \%$ decline in $r$.

Keywords: Engraulis encrasicolus ; NW Mediterranean Sea ; Environmental variability ; Dynamic Energy Budget theory ; Growth ; Fecundity 


\section{INTRODUCTION}

European anchovy, Engraulis encrasicolus, are of great economical and ecological importance due to high relative abundances, nutritional quality and intermediate level in marine food webs (Plounevez and Champalbert, 2000). However, as a consequence of their r-selected life history strategy (fast growth, early maturity onset and a short life cycle of 3-4 years, Somarakis et al. 2004) and plankivorous diet (Tudela and Palomera, 1997; Plounevez and Champalbert, 2000), individual and population performances are highly responsive to environmental variability (Katara et al. 2011). Indeed, throughout its distribution, stocks of European anchovy have been shown to fluctuate over several orders of magnitude between years (Lluch-Belda et al. 1989; Regner, 1996; Palomera et al. 2009; Martín et al. 2012; Petitgas et al. 2012). Such intra-specific and spatiotemporal plasticity places constraints on directed exploitation and creates difficulties in assessing stock dynamics for fisheries management. This has prompted the need to better understand the mechanisms through which anchovy populations respond to short-term (seasonal and inter-annual) and long-term (decadal) environmental fluctuations.

Acquiring adequate time and spatially integrated, biotic and abiotic field data to answer complex processdriven questions in marine ecosystems is logistically impractical using conventional shipboard measurements. In response, the application of a range of stage-structured bioenergetics and individual-based population modelling (IBM) approaches have expanded in recent years, largely due their capability of evaluating size dependent processes to different environmental scenarios. For E. encrasicolus, bioenergetics models have been successfully implemented to distinct populations in the northern Aegean Sea (Politikos et al. 2011), Black Sea (Oguz et al. 2008) and Bay of Biscay (Pecquerie et al. 2009) yielding important information on the life cycle dynamics. In the NW Mediterranean Sea, although modelling studies have greatly advanced our understanding of anchovy larval bioenergetics and transport dynamics (Nicolle et al. 2009; Ospina-Alvarez et al. 2011) there is currently no modelling framework for which to examine the growth trajectories and lifehistory processes over the entire life-cycle of an individual and consequently, population level processes.

The Gulf of Lions (GoL, $42-44^{\circ} \mathrm{N}, 3-6^{\circ} \mathrm{E}$, Fig. 1) is one of the main spawning areas for European anchovy in the Mediterranean Sea (García and Palomera, 1996). In this area, climate and ecosystem variability operates over a range of spatial and temporal scales. Both temperature and primary production follow annual cycles characterized by strong seasonality (Razouls and Kouwenberg 1993, Gaudy et al. 2003, Sabatés et al. 2007, Lazzari et al. 2011). Spatially, there are clear West - East and inshore - offshore gradients of increasing temperature, salinity and oligotrophy (Antoine et al. 1996), which affects phytoplankton biomass and production (Pitta et al. 2001; Gaudy et al. 2003). Annual anchovy biomass estimates in the GoL between 1995 and 2011 have ranged between 19,000 to 118,000 MT (Pelmed surveys data, Roos et al. 2011). Although fishing activities for anchovy in the GoL have not been in operation since 2009, the size and structure of stocks has recently seen unbalance with its biomass declining 3-fold since 2001 and its 2009 to 2011 age-structure dominated by small and young (< age-2) individuals (Palomera et al. 2009; Roos et al., 2011). Our assumption is that the substantial change in this population's state is due to a recent, abrupt or prolonged disturbance such as a shift in oceanographic and/or ecological conditions. Although such an event has not been documented in the GoL, the Mediterranean Sea is considered one of the most sensitive areas in the world with respect to effects of climate variability (Lionello et al. 2006) and long-term shifts in plankton productivity and temperature have been recorded (Marty and Chiaverini, 2002; Vandromme et al. 2011).

The main objective of this study was to better understand the mechanisms through which European anchovy in the GoL (and globally) respond to short-term environmental change. Specifically, we sought to address the following questions: (1) What are the physiological mechanisms explaining high variation in anchovy demographic vital (growth and fecundity) rates? and (2) How does the rate of population change respond to changes in temperature and food conditions? To answer these questions, we offer a modeling approach based on Dynamic Energy Budget (DEB) theory (Kooijman, 2010) which describes energy fluxes $\left(\mathrm{J}^{-1}\right)$ during various physiological processes: growth, reproduction and maintenance. We chose DEB theory due to its consistency with first principles (i.e. conservation of energy), and its strong capacity to mechanistically examine physiological responses in fish to external parameters (temperature and food resources) and quantify the consequences in terms of growth, condition and reproductive output (Van der Veer et al. 2001; Pecquerie et al. 2009; Augustine et al. 2011). 


\section{MATERIALS AND METHODS}

\subsection{Overview}

For the population of E. encrasicolus in the Bay of Biscay, a DEB model has been implemented to gain greater insight into the effect of environmental variability on growth, batch fecundity and spawning dates (Pecquerie et al. 2009), the latter being an important component of larval dispersal studies. We first extended this model to apply it to the GoL anchovy taking into consideration different environmental conditions (higher mean annual temperatures and different food dynamics) and growth data (higher initial growth rates and lower maximum length) than that observed in the Bay of Biscay. We further extended the model by taking into account field observations of seasonal variations in gonadosomatic indices over an extended period (2002-2011). After appropriate calibration and evaluation of individual-based traits, the GoL DEB model was then used as the foundation of an individual-based population model (an IBM) in which individuals were treated as explicit entities using an $i$-state, cohort-based configuration. Lastly, we utilized both the DEB model and its associated IBM to examine the sensitivity of individual vital (growth and fecundity) rates and population growth rates to different climate scenarios. Accordingly, here we describe the DEB and DEB-IBM formulations separately before detailing: input and output variables, initialization procedures and the design and analyses of simulations. It is noted here that both of these models (DEB and DEB-IBM) are non-spatial and time is represented continuously (ordinary differential equations) based on daily time-steps.

\subsection{Model descriptions}

\subsubsection{DEB: Individual-level processes}

An individual is characterized by four state variables: reserves $(E$, units: $J)$, structure $\left(V\right.$ and $E_{V}$, units: $\mathrm{cm}^{3}$ and $\mathrm{J}$, respectively), reproduction ( $E_{R}$, units: $\left.\mathrm{J}\right)$ and gametes $\left(\mathrm{E}_{\mathrm{GAM}}\right.$, units: $\mathrm{J}$ ) each presented in Table 1. Core model parameters (Table 2) are directly related to processes controlling the four state variables, where fluxes are formulated in joules per day $\left(\mathrm{J} \mathrm{d}^{-1}\right.$, Table 1). According to the underlying assumptions of the Dynamic Energy Budget (DEB) theory (Kooijman 2010), metabolic processes are proportional to structural surface area or volume and a full balance for mass and energy. Briefly, the model dictates that energy is assimilated $\left(\dot{p}_{A}\right)$ from food and transferred into reserve (E, Fig. 2). From here, fixed fractions ( $\kappa$ and $1-\kappa)$ of catabolized energy $\left(\dot{p}_{C}\right)$ are mobilized and allocated to either soma $\left(\mathrm{E}_{\mathrm{V}}\right)$ or maturation/reproduction $\left(\mathrm{E}_{\mathrm{R}}\right)$. Increase in structure (V) regulates transitions between five developmental stages (yolk-sac larvae, early-stage larvae, late-stage larvae, juveniles and adults, Table 3$)$. All energy allocated to the reproductive buffer before puberty $\left(\mathrm{V}<\mathrm{V}_{\mathrm{p}}\right)$ is lost to maturation $\left(E_{R}=0\right)$. For adults, energy is stored in $E_{R}$ until the spawning season starts $\left(\mathrm{SST}>16^{\circ} \mathrm{C}\right)$ at which time, energy can be mobilized $\left(i_{\ldots}\right)$ to produce gametes $\left(\mathrm{E}_{\mathrm{GAM}}\right)$ (Table 1 and further detailed in section 2.2.1.1 below).

Food intake is controlled by a scaled (dimensionless and Holling type-II) functional feeding response $(f)$ curve that ranges between 0 (no food intake) and 1 (maximum food intake). It is given by the equation $f(X)=\frac{X}{X+K}$ where for a given food type, $\mathrm{X}$ gives its density and $\mathrm{K}$ its half-saturation constant (see section 2.3.1 for the description of the different food types). Energy reserves (E) are replenished by assimilated food, $\dot{p}_{A}$ which explicitly links the rate of feeding $\left(\dot{p}_{X m}\right)$ with the size of the organism and $f$. To calculate the maximum assimilation rate $\left\{\dot{p}_{A m}\right\}$ we multiplied our estimates of the maximum feeding rate $\left\{\dot{p}_{X m}\right\}$ and the food assimilation efficiency (ae), which was given a constant value of 0.71 based on that of E. capensis (James et al. 1989).

Temperature effects on metabolic rates, including maximum assimilation $\left\{\dot{p}_{A m}\right\}$ and somatic maintenance $\left[\dot{p}_{\mathrm{M}}\right]$, 'were accounted for using the following correction equation:

$$
\begin{aligned}
c(T) & =\exp \left(\frac{T_{\mathrm{A}}}{T_{\text {ref }}}-\frac{T_{\mathrm{A}}}{T}\right) \text { for }\left[\dot{p}_{\mathrm{M}}\right]_{T}=\left[\dot{p}_{\mathrm{M}}\right]_{\text {ref }} \cdot c(T) \text { and } \\
\left\{\dot{p}_{\mathrm{Am}}\right\}_{T} & =\left\{\dot{p}_{\mathrm{Xm}}\right\}_{\text {ref }} \cdot \text { ae } \cdot c(T)
\end{aligned}
$$


where $\mathrm{T}$ is the water temperature in Kelvin (Table 3), $\mathrm{T}_{\text {ref, }}$ the reference temperature, set at $289 \mathrm{~K}$ (i.e $16^{\circ} \mathrm{C}$ ) and $\mathrm{T}_{\mathrm{A}}$ is the Arrhenius temperature for anchovy, set at $9800 \mathrm{~K}$ after Pecquerie et al. (2009).

\subsubsection{Reproduction}

We included a reproductive module to emulate as best as possible the life-history of European anchovy which shows group-asynchronous, indeterminate development of oocytes and multiple batch spawning during a protracted, annual reproductive season in which high numbers of gametes are released. In NW Mediterranean, anchovy typically spawn in SST of between 16 to $24^{\circ} \mathrm{C}$ between April to October, with a peak in summer (June to July) (Palomera, 1992, Palomera et al. 2007). Consequently, in our model, spawning events were regulated by a SST threshold (TR) of $>16^{\circ} \mathrm{C}$. Participation in the spawning season were reserved for adults $\left(\mathrm{V}>\mathrm{V}_{\mathrm{p}}\right)$ only. As individual spawning intensity (energy investment), timing (intervals between batches) and duration (length of the reproduction season) depend on adult physiological (size, energetic and maturation) status which is influenced by their past and present environment (food supply and temperature), we determined two rules for which a single batch of gametes could be produced. These included:

1) sufficient energy must be available in the gametes; $0.6 \times E_{G A M}>=E_{\text {batch }}$, with $E_{\text {batch }}=E_{\text {egg }} \times\left(R F_{\text {batch }} \times V\right)$, and

2) the oocytes of each batch, must have had enough time to reach full development, $\mathrm{O}_{\text {Dev }}>\mathrm{ODev}_{\mathrm{Time}}$

For these rules, we assumed that energy content of $1 \mathrm{egg}, \mathrm{E}_{\text {egg }}$ was $0.15 \mathrm{~J} \mathrm{egg}^{-1}$ based on mean values of $5600 \mathrm{~J}$ $\mathrm{g}^{-1} \mathrm{~W}_{\mathrm{W}} \mathrm{egg}^{-1}$ (Valdés, 1993) and $27.7 \mu \mathrm{g} \mathrm{egg}^{-1}$ (Somarakis, 1999) as used by Politikos et al (2011). The relative batch fecundity $\left(\mathrm{RF}_{\text {batch }}\right)$ was set at 550 eggs cm${ }^{-3}$ after considering mean estimates of between 226 to 646 eggs $\mathrm{g}^{-1}$ of gonad-free weight of mature female (Somarakis et al. 2004) and a (wet) structural density of $1 \mathrm{~g} \mathrm{~cm}^{-3}$ (van der Veer et al. 2001). In anchovy, maturation of oocytes and vitellogenesis are a continuous cycle with oocytes typically distributed in 1 to 3 modes with each mode representing a single spawning batch (Motos, 1996). To reflect these processes, in our model only a fraction $\left(0.6 \times \mathrm{E}_{\mathrm{GAM}}\right)$ of the energy mobilized to gametes $\left(\mathrm{E}_{\mathrm{GAM}}\right)$ was allocated to the final maturation oocyte stages whilst the resting 0.4 was dedicated to the continued preparation of less developed oocytes. For the final batch of the season, $100 \%$ of the remaining energy in the gametes $\left(\mathrm{E}_{\mathrm{GAM}}\right)$ was utilized. Final oocyte development time of any one batch was determined by the equation, $\operatorname{ODev}_{\text {Time }}(\mathrm{d})=4900 \mathrm{SST}^{-2.29}$, with SST the sea surface temperature in ${ }^{\circ} \mathrm{C}$, which incorporated the temperature correction function used in estimating egg development times (Ospina-Alvarez et al. 2011). The implementation of these rules meant that spawning frequency, amplitude and intensity (fecundity rates) were limited by the mother's size, energy intake and external temperatures. Age-specific batch fecundity was computed as: $\mathrm{F}_{\text {batch }}=\mathrm{E}_{\text {batch }} / \mathrm{E}_{\text {egg }}$ and seasonal or annual fecundity, $\operatorname{F}_{\mathrm{YEAR}}(i)=\sum_{k} F_{b a t c h}(t)$.

\subsubsection{Maintenance and survival}

Several maintenance fluxes were included in our model with the aim of strengthening the link between reproductive effort and environmental variability. Somatic maintenance costs $\left(_{i} \ldots\right)$ are proportional to structural volume and consistently have priority over growth. Where basic maintenance costs cannot be covered, additional maintenance can occur via a second flux, $\dot{p}_{M 2}$, in which takes priority over the allocation flux to the gametes $\dot{p}_{R 2}$ (taken after Bernard et al. 2011). To account for the occurrence of atresia whereby under poor environmental conditions resorption of vitellogenic oocytes is known to occur in anchovy (Hunter and Macewicz, 1985), the model allowed for further maintenance costs $\left(i_{\ldots} ..\right)$ to be taken from the energy allocated to the gametes ( $\mathrm{E}_{\mathrm{GAM}}$ ) during the spawning season (Fig. 2). If somatic rates become negative $\left(\kappa \dot{p}_{C}<\dot{p}_{M}+\dot{p}_{M 2}+\dot{p}_{R 2}\right)$ and maturity maintenance costs can no longer be paid $\left((1-\kappa) \dot{p}_{C}<\dot{p}_{J}\right)$, the individual was determined dead (through the cause of starvation). We also imposed a lethal SST for eggs which was set to $>26^{\circ} \mathrm{C}$ as anchovy in the Mediterranean Sea have been observed to spawn successfully in SST as high as $25.5^{\circ} \mathrm{C}$ (Palomera 1992).

\subsubsection{IBM: Population-level processes}


The DEB model was used as the foundation of an individual based model (IBM) with the purpose of examining population-level processes and emerging dynamics in a bottom-up approach. The IBM is an $i$-state configuration model (Maley and Caswell 1993) in which large numbers of cohorts (defined here as all individual eggs born on the same day), are followed as discrete entities. The $i$-states in our model follow the DEB characteristics of individuals; their size $(V)$, energy reserves $(E)$, or reproduction output $\left(\mathrm{E}_{\mathrm{R}}, \mathrm{E}_{\mathrm{GAM}}\right.$ and $\left.E_{\text {batch }}\right)$, the later which determines the recruitment of the virtual population. We recognized that only the female fraction (0.5) of the population produced eggs with the production of spermatozoa assumed to be just as energetic for males than females based on total lipid content (N.Bodin, unpublished data) and gonadosomatic index (GSI, Roos et al. 2011) data.

Simulated populations have an undefined number of potential daily cohorts with a new cohort $(i+1)$ potentially generated on each day $(t)$. Initial abundance $\left(\mathrm{N}_{i+1}\right.$, \# individuals) of cohort $(i+1)$ is given by the number of eggs spawned according to the equation: $N_{\text {eggs }}(t) \cdot=\sum_{i} F_{\text {batch }_{i}}(t)$. This means that the abundance of any one cohort $\left(\mathrm{N}_{i}\right.$, \# individuals) can differ substantially to another, as does their capacity to grow and reproduce due to different food availability and temperature conditions imposed over the spawning season. The abundance of each cohort is only influenced by imposed daily mortality rates $\left(\mathrm{M} \mathrm{d}^{-1}\right)$ that change according to stage-specific size thresholds (given in Table 3) and are based on estimates taken for the NW Mediterranean (Palomera and Lleonart, 1989; Pertierra et al. 1997; Palomera et al. 2007). As mortality rates decline with increasing length (and age), cohorts that grow faster during the early life stages (yolk-sac larvae) will have lower mortality rates applied earlier than slower growing cohorts. An entire cohort could also die at any given time from either starvation or thermal stress for eggs (according to the rules described in section 2.1.1.2). In this study, fishing mortality was not taken into consideration as operations in the Gulf of Lions ceased in 2009, thus the abundance (\# ind.) of each cohort (i) was calculated as: $\frac{d N_{i}}{d t}=N_{i} \cdot M_{i}$

From here, the abundance of the entire population can be computed at given at any time as: $N \cdot=\sum_{i} N_{i}$ Likewise, the total stock biomass (B, Metric Tons MT), which includes cohorts of all stages (eggs - adults) can be computed as: $B \cdot=\left[\sum_{i} N_{i} \cdot W_{w w, i}\right] \times 10^{-9}$, with $W_{w w, i}$ the wet weight $(\mathrm{g})$ of an individual in cohort $i$.

\subsection{Model Inputs}

\subsubsection{Environmental variables}

Individual traits, including stage durations are dependent on two forcing variables: food density (X) and temperature (T). Both variables were specified for five distinct life-cycle stages (yolk-sac larvae, early-larvae, late-larvae, juveniles and adults as indicated in Table 3) based on important life-history events including sizeat-first-(exogenous) feeding, metamorphosis and puberty. We also accounted for the fact that anchovy occupy deeper (and thus, colder) waters with increasing age as outlined by Palomera et al. (2007). Similarly, choice of food type was based on dietary data for larvae, juveniles and adults in the GoL, which consists of mainly phytoplankton, cladocerans (small mesoplankton) and copepods (large mesoplankton or zoopmlankton), respectively (Costalago et al. 2012).

Due to the difficulties associated with capturing intricate and poorly understood temporal patterns of the food (plankton) supply of anchovy in the GoL, we applied a sinusoidal function to $\mathrm{X}$ to be consistent with current knowledge of strong seasonal changes in plankton abundances in NW Mediterranean Sea (Gaudy et al. 2003; Sabatés et al. 2007; Lazzari et al. 2011; Vandromme et al. 2011). A similar function was used for temperature, where an amplitude $a$, phase shift of the sinusoid $\omega$, and a mean value $\left(\mathrm{X}_{\text {mean }}\right.$ or $\left.\mathrm{T}_{\text {mean }}\right)$ were used in the equation: $f(\mathrm{t})=\mathrm{X}_{\text {mean }}\left(\right.$ or $\left.\mathrm{T}_{\text {mean }}\right)+a \sin (2 \pi(\mathrm{t}+\omega) / 365)$. 
Produced sinusoidal curves were consistent with in situ observations and hydrodynamic model output (Fig. 3) taken for the GoL (Fig. 1). Specifically, for larvae, model forcing was based on real-time satellite-derived sea surface temperature $\left({ }^{\circ} \mathrm{C} \mathrm{SST}\right)$ and surface chlorophyll- $a\left(\mathrm{chl}-a \mathrm{mg} \mathrm{m}^{-3}\right)$ data obtained for the GoL $\left(42-44^{\circ} \mathrm{N}, 3-\right.$ $6^{\circ}$ E) between 2004 to 2010 (Fig. 2) using interpolated MODIS and SeaWiFS (NASA) satellite images. For juveniles and adults, daily mid-water temperature $\left({ }^{\circ} \mathrm{C}\right.$ MWT) values were obtained by the validated hydrodynamic model MARS-3D applied to the GoL (Lazure and Dumas 2004). Juvenile and adult food densities ( $\mathrm{X}_{\text {mean }}$ and amplitude, $a$ ) were based on in situ biomass values of small mesoplankton (sized $0.2-0.5$ $\mathrm{mm}$ ) and large mesoplankton (zooplankton sized $>0.5 \mathrm{~mm}$ ), respectively recorded in the GoL during (Costeau 4 and 6) surveys undertaken in April $2010\left(\right.$ mean $=134 \mathrm{mg}$ zooplankton $\left.\mathrm{m}^{-3}\right)$ and January $2011($ mean $=81 \mathrm{mg}$ zooplankton $\mathrm{m}^{-3}$ ) (Espinasse, 2012). We allowed for a time-lag of 10 and 15 days between chl-a and small mesoplankton and zooplankton, respectively (by altering the phase shift, $\omega$ in the sinusoid curve for each lifehistory stage, Table 3) which is coherent with field observations (Matín et al. 2008). Each sinusoid curve was consistent with knowledge that, in the GoL, sea surface temperatures (SST) typically peak at the end of summer (July-September; $\sim 24^{\circ} \mathrm{C}$, Marty and Chiaverini, 2002) while highest phytoplankton productivity occurs in late winter-early spring (February-April; Estrada, 1985; Siokou-Frangou, 1996). Based on satellite (MODIS and SeaWiFS, NASA) derived data, over a relatively short (7-9 year) period during $2002-2010$, high inter-annual variability (up to $8 \%$ for chl-a measurements), moderate spatial variation and a mean annual rise of $0.22^{\circ} \mathrm{C}$ in SST is observed in the GoL (Fig. 3).

\subsubsection{Parameterisation}

DEB model parameters were estimated using data provided in Appendix I and a simplex method (Lika et al. 2011) supplied in the DEBtool software (Kooijman et al. 2008). Further parameterization was achieved using biometric data for juveniles and adult specimens of E. encrasicolus (5.8-18.2 cm total length (TL) and 2.9-40 g total wet weight $\left(\mathrm{W}_{\mathrm{ww}}\right), \mathrm{n}=11504$ ) collected in the GoL from 2002-2011 (Roos et al. 2011, unpublished data). Growth data for larvae were obtained from Palomera et al. (unpublished data) and consisted of specimens (1.8$5.4 \mathrm{~cm}$ TL, 0.018-1.32 $\mathrm{g} \mathrm{W}_{\mathrm{ww}}, \mathrm{n}=854$ ) collected in GoL during Pelmed surveys in July, 2007. Although $E$. encrasicolus displays sexual dimorphism with age-2 females being on average $1.4 \mathrm{~cm}$ larger than males (unpublished data), averaged population values were used to calibrate parameters, mainly due to gender similarities in seasonal growth, condition factors and gonadosomatic (GSI) index patterns (Basolini et al. 2006; Roos et al. 2011, unpublished data). The half-saturation constant was calibrated for each of the three local food sources, independently, using larvae weight-length relationship (phytoplankton), juvenile weight-at-age data (small mesoplankton) and adult weight-at-age and condition index data (zooplankton).

\subsubsection{Initialization}

All (DEB and IBM) simulations followed individuals from their date of hatching (day 0 ) and included a period of time without food $\left(\mathrm{X}=0\right.$ where $\left.\mathrm{V}<\mathrm{V}_{\mathrm{ab}}\right)$ as yolk-sac is still present. Initial values for state variables were estimated using larvae growth (Ospina-Alvarez et al. 2011) and proximate composition (Rossi et al. 2006; Costalago et al. 2011) data of which we obtained: $\mathrm{V}_{0}=0.00013 \mathrm{~cm}^{3}, \mathrm{E}_{0}=0.11 \mathrm{~J}, \mathrm{E}_{\mathrm{V} 0}=0.025 \mathrm{~J}$ and $\mathrm{E}_{\mathrm{R} 0}$ and $\mathrm{E}_{\mathrm{GAM} 0}=0 \mathrm{~J}$. This gave length- and weight-at-first feeding (day-4) values of $0.36 \mathrm{~cm}$ and $0.0029 \mathrm{~g}$, respectively which are consistent with GoL field estimates (Ospina-Alvarez et al. 2011).

All population (IBM) simulations were initialized with 1 cohort, consisting of 1 yolk-sac larvae and a spin-up run of 5-years was performed. The maximum lifespan of an individual was set at 1460 days (4 years old) at what time remaining individuals in a given cohort were removed.

\subsection{Model outputs and evaluation}

To evaluate the outputs given by the DEB model, state variables were related to biometric measurements typically collected in field surveys: total length $(\mathrm{L}, \mathrm{cm})$, total body weight $\left(\mathrm{g} \mathrm{W}_{\mathrm{ww}}, \mathrm{W}_{\mathrm{dw}}\right)$, gonadosomatic index (GSI), Fulton's condition index $\left(\mathrm{K}_{\mathrm{FUL}}, \mathrm{g} \mathrm{cm}^{-3}\right)$ and energy density content $\left(\mathrm{J} \mathrm{g}^{-1}\right)$ (Table 1). Simulated structural volume $(\mathrm{V})$ was converted to length using a shape coefficient $(\delta)$ where $\mathrm{L}=\mathrm{V}^{1 / 3} / \delta$. As anchovy larvae have different (more cylinder) shape to juveniles and adult, separate shape coefficients were estimated by fitting a weight-length relationship $\left(\frac{W_{w w}{ }^{1 / 3}}{L}\right)$ to larvae $(<$ length at metamorphosis, $3.7 \mathrm{~cm})$ data $(\mathrm{n}=340$; $\left.\delta_{\text {larvae }}=0.154\right)$ and to a dataset consisting of juveniles less than $9 \mathrm{~cm} \mathrm{TL}$, total length $\left(\mathrm{n}=460 ; \delta_{\text {Adult }}=0.169\right)$ so 
that the reproductive buffer would not be included. To exclude the effects of abrupt shape changes between larvae and adults, we allowed the shape coefficient to change as a function of size from day- 0 until size of metamorphosis $\left(\mathrm{V}>\mathrm{V}_{\text {morph }}\right)$ using the equation $\delta=0.0025 \mathrm{~V}+\delta_{\text {larva }}$. The threshold structural volume at first (exogenous) feeding $\left(\mathrm{V}_{\mathrm{ab}}\right)$, metamorphosis $\left(\mathrm{V}_{\text {morph }}\right)$ and puberty $\left(\mathrm{V}_{\mathrm{p}}\right)$ was estimated at $0.000164,0.53$ and $5.43 \mathrm{~cm}^{3}$, respectively, based on the equation $\mathrm{V}=(\delta \mathrm{L})^{3}$. To convert state variables $(\mathrm{J})$ into units of weight $(\mathrm{g}$ $\left.\mathrm{W}_{\mathrm{dw}}\right)$, separate conversion factor were used for: structure $\left(\mathrm{E}_{\mathrm{V}}, \mu_{\mathrm{V}}=19.9 \mathrm{KJ} \mathrm{g}^{-1}\right)$, reserves $\left(\mathrm{E}\right.$ and $\mathrm{E}_{\mathrm{R}}, \mu_{\mathrm{E}}=35.2 \mathrm{KJ}$ $\left.\mathrm{g}^{-1}\right)$ and gametes $\left(\mathrm{E}_{\mathrm{GAM}}, \mu_{\mathrm{G}}=33.2 \mathrm{KJ} \mathrm{g}^{-1}\right.$, Table 2$)$. These parameters values were based on mean proximate composition (Rossi et al. 2006; Kaya and Turan, 2008; Costalago et al. 2011; C. Munschy and N. Bodin, unpublished data) and weight data available for tissues typically associated with energy storage (liver, viscera, skin lipids) and structure (muscle, skeletal), where the energetic value of lipid was considered to be $37 \mathrm{KJ} \mathrm{g}^{-1}$ and protein and carbohydrates $19.5 \mathrm{KJ} \mathrm{g}^{-1}$. To compute gonad weight $\left(\mathrm{g}, \mathrm{W}_{\mathrm{dw}}\right)$, we assumed that gonads consisted of a fraction (0.015) of structure $\left(\mathrm{E}_{\mathrm{V}}\right)$ during the course of an individuals life cycle while the rest (and majority) of the dry weight was attributed to $\mathrm{E}_{\mathrm{GAM}}$ (Table 1). For all weight estimates, the dry to wet conversion coefficient, $\gamma$ was fixed at 4.1 taken as the mean of GoL biochemical composition data (C. Munschy unpublished data).

For population simulations, model output was expressed in terms of log-transformed, continuous population growth rates to condense complex (multiple-cohort and age-specific biomass) information from the analysis. Growth rates $\left(\right.$ year $\left.^{-1}\right)$ in population biomass $(B)$ were projected over a given interval and was calculated as: $r=\frac{\ln (B(t+\Delta t) / B(t))}{\Delta t}$.

\subsection{Sensitivity and scenario based analyses}

The sensitivity of intrinsic (model-specific) parameters was investigated using a traditional one-parameter-at-atime analysis in which each model parameter was separately varied by $\pm 10 \%$ and the model's performance was evaluated (Table 2) through the calculation of a simple sensitivity index (SI) using the following equation:

$$
S I=\frac{1}{n} \sum_{t=1}^{n} \frac{\left|W_{t}^{\mathrm{O}}-W_{t}^{1}\right|}{W_{t}^{\mathrm{O}}} * 100(\%)
$$

where $n$ is the number of simulated days, $W_{t}^{0}$ is the total wet weight (or length) predicted with the standard simulation time $t$, and $W_{t}^{1}$ is the total wet weight (or length) predicted with the new parameter value at time $t$.

The sensitivity of external (food availability, temperature and natural mortality) factors on individual vital rates (growth and fecundity) and population growth rate estimates were investigated through a number of scenariobased simulations. In each scenario, model-specific parameters remained the same and one external factor was altered while other external factors were set to a standard value (Table 3 and Fig. 3). This allowed us to evaluate the mechanistic connection between an individual environmental factor and anchovy life history variability and growth potential. Firstly, we ran the bioenergetics model explicitly over a 4-year lifespan of an individual (hatched on the 1 June) under standard GoL conditions and then under altered $\left( \pm 20 \%\right.$ food, $X_{\text {mean }}$ or $\pm 10 \%$ temperature, $\mathrm{T}_{\text {mean }}$ ) conditions. In association with this test, we also projected the effects of different hatching dates on growth and development relative to the standard GoL environmental conditions.

Secondly, we examined the influence of a one-at-a-time proportional (5\% or 7-day) change to each mean environmental factor ( $T_{\text {mean }}, X_{\text {mean }}, M$, mortality rates and $\omega$, phase shift of the food peak indicated in Table 3 ) over a 1-year period on individual fecundity rates (of an individual hatched on the 1 June) and over 1 and 5 year time scales on population growth rates ( $r$, using the IBM). Specifically, we assessed the effect of:

1) Magnitude changes in temperature, simulating the $T_{\text {mean }}$ and $T_{\text {mean }} \pm 5$ to $30 \%$.

2) Magnitude changes in food resources, simulating the $X_{\text {mean }}$ and $X_{\text {mean }} \pm 5$ to $30 \%$.

3) Temporal food variation through adjusting the phase shift $(\omega)$ of the mean sinusoidal food availability by \pm 7 to 42 days (thus, food peaking between mid-February to mid-May). 
4) For the population growth (IBM) simulations only, magnitude changes in natural egg and larvae mortality rates, simulating mean mortality rates \pm 5 to $30 \%$.

All IBM simulations were run for 10-years and included a 5-year baseline run, under 'standard', nonmanipulated GoL environmental conditions (Table 3 and Fig. 3) to have an initial condition close to a stable age distribution. Proportional one-at-a-time changes in an environmental factor occurred after 5 years and population (biomass) growth rates were calculated between years 6-7 and 5-10 to examine differences between 1 -year or 5 year periodic changes, respectively.

\section{RESULTS}

\subsection{Model estimates}

\subsubsection{Individual traits}

Under standard (Fig. 3 and Table 3$)$ and adjusted forcing ( $\pm 20 \%$ of $X$, food density and $\pm 10 \%$ of $\mathrm{T}$, temperature) regimes, a 4-year model simulation of an individual hatched on the $1^{\text {st }}$ June, efficiently captured life-history and seasonal growth patterns in addition to much of the individual variability observed within the existing dataset available for anchovy in the Gulf of Lions (Fig. 4 and 5). Furthermore, predicted rates of energy assimilation, consumption and growth (in length and weight) varied according to the developmentalstage and in mature adults varied seasonally (Table 4). Specifically, simulated growth rates in length declined with fish age and were highest for larvae $\left(0.6\right.$ to $\left.0.85 \mathrm{~mm} \mathrm{~d}^{-1}\right)$, followed by juveniles $\left(0.11\right.$ to $\left.0.6 \mathrm{~mm} \mathrm{~d}^{-1}\right)$. Growth rates for adults only increased from March to October with highest monthly mean growth observed in June and July (Age-1 $=0.14$, Age- $2=0.10$, Age-3 $=0.04$, Age- $4=0.03 \mathrm{~mm} \mathrm{~d}^{-1}$, Table 4). In weight, for all life-history stages, highest positive growth rates were observed at the end of June (50 to $71 \mathrm{mg} \mathrm{d}^{-1}$ ) while negative growth in adults occurred in November and December $\left(-8\right.$ to $\left.-34 \mathrm{mg} \mathrm{d}^{-1}\right)$. For mature adults, considerable weight loss due to the release of gametes was equally observed whereby, directly after a spawning event, total weight of mature age- 2 females decreased on average $4-10 \%$ (Fig. 4B zoom). For an age- 2 individual, total weight increased $26 \%$ during the spawning season, indicating that feeding met most of the energetic requirements for reproduction in addition to growth. In the standard model run, imposed starvation $(\mathrm{X}=0)$ at $\mathrm{T}_{\text {mean }}=18.5^{\circ} \mathrm{C} \mathrm{SST}$ and $16^{\circ} \mathrm{C}$ MWT caused death after 4 days in early larvae (of 20-days old) while over-wintering adults (of 1000 days old), endured 90 days.

Simulated energy density increased (from $3430 \mathrm{~J} \mathrm{~g}^{-1} \mathrm{~W}_{\mathrm{ww}}$ ) exponentially for anchovy until $\sim 8 \mathrm{~cm}$ and then varied seasonally after the age of puberty between $5697-6510 \mathrm{~J} \mathrm{~g}^{-1} \mathrm{~W}_{\mathrm{ww}}$ (Table 4) which is equivalent to 23-24 $\mathrm{kJ} \mathrm{g}^{-1} \mathrm{~W}_{\mathrm{dw}}$. Relative contributions of soma $\left(\mathrm{E}_{\mathrm{V}}\right)$ and reserves $\left(\mathrm{E}+\mathrm{E}_{\mathrm{R}}+\mathrm{E}_{\mathrm{GAM}}\right)$ to body (dry) weight were simulated at $75-85 \%$ and $15-25 \%$, respectively. From the model output, daily energy expenditures $\left(\mathrm{kJ} \mathrm{d}^{-1}\right)$ which is the sum of all energy requirements for growth, maturation and maintenance increased linearly with total body weight $\left(\mathrm{kJ} \mathrm{d}^{-1}=6.18 \mathrm{TW}\left(\mathrm{g} \mathrm{W}_{\mathrm{ww}}\right)+5.09, \mathrm{R}^{2}=0.99\right)$. Individual feeding rates $\left(\mathrm{J} \mathrm{d}^{-1}\right)$ increased with age and varied according to seasonal differences in environmental conditions (Table 4). Multiplying the feeding rate of anchovy by an assumed energy density of copepods (2580 J g prey ${ }^{-1}$, as used by Politikos et al.

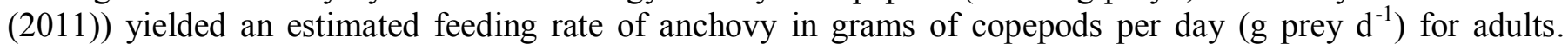
Using these values, the proportion of total body weight (BW) consumed daily ranged between 2.4 to $4.9 \% \mathrm{BW}$ $\mathrm{d}^{-1}$ (Table 4).

Simulated reproduction output, including batch (annual number and eggs/batch) and seasonal (total number of eggs) fecundity increases with individual size, SST and food availability (Fig. 4E). Specifically, under standard forcing conditions, at the first year of spawning (age-1), 19 batches of between 4500-8200 eggs per batch were simulated while at age-4, comparably higher seasonal fecundity rates (including 23 batches and 11,500-13,600 eggs per batch) were simulated (Table 5). Simulated annual reproduction output increased non-linearly with age with values more than double for age-4 females than age-1 (Table 5 and Fig. 4B). Inter-spawning intervals were typically longer (5 - 10 days) at the start and end (May and August) of the season than those during June and July ( $3-5$ days). Under constant food conditions, a scaled functional response of $f=0.55$ (X $=41 \mathrm{mg}$ zooplankton $\mathrm{m}^{-3}$ ) was found to be the threshold at which adults were able to produce gametes during the entire spawning season. For an age-2 individual under starvation $(\mathrm{X}=0)$ during the peak of the reproductive season $\left(1^{\text {st }} \mathrm{July}\right)$, the model predicted that atresia occurred $\left(\dot{p}_{L 1}>0\right)$ after 4 days. 


\subsubsection{Population traits}

By simulating multiple cohorts/individuals in an $i$-state configuration and stage-structured population model, inter-individual variability in growth trajectories and reproductive potential became apparent, due to seasonal and inter-annual variability in environmental conditions. As was shown by Pecquerie et al. (2009) for the Bay of Biscay anchovy population, individual anchovy in the GoL that are born at the start of the reproductive season $\left(1^{\text {st }}\right.$ April) have higher growth and fecundity rates during their entire lifetime than those born at the end (1 October). Intra-specific variation in size was high during the first year (up until $7 \mathrm{~cm}$ TL and $7 \mathrm{~g} \mathrm{~W}_{\mathrm{ww}}$ Fig. $5 \mathrm{~A}-\mathrm{B})$ and decreased with age. Individuals born later in the season took longer to reach maturation and had much lower seasonal fecundity rates at age-1 $(78 \%$ lower for an individual born on the 1 September than on the 1 May), age-2 (24\%), age-3 (19\%) and age-4 (8\%). In a 10-year long simulation under standard environmental conditions, the IBM estimated a mean population (log-transformed biomass) growth rate $(r)$ of 3.5 year $^{-1}$. These values were then used as references when studying scenarios of environmental changes and their impact the population growth rate.

\subsection{Model sensitivity and scenario-based simulations}

Sensitivity analysis of the model parameters showed that those governing food consumption $\left(\left\{\dot{p}_{X m}\right\}\right.$ and ae) and energy allocation (Kappa, $\left[\dot{p}_{M}\right]$ ) have the most important effects on growth with sensitivity indices reaching as high as $10 \%$ and $25 \%$ on length and weight, respectively (Table 2 ). For example, a $10 \%$ increase in the maximum ingestion $\left\{\dot{p}_{X m}\right\}$ caused a $20 \%$ increase in growth rates for early life-history stages.

Scenario simulations were performed to examine the impact of magnitude changes in temperature, food availability and egg and larvae mortality rates in addition to changes to the timing of the peak food availably $(\omega$, phase shift) relative to the spawning season. For an individual (hatched on the 1 June), DEB simulation results predicted that both the effect of temperature and date of hatching (which combined temperature and food effects) on anchovy growth, decreased with age, while the impact of food availability was more apparent in adults ( $>$ age-1, Fig 4 and 5). Indeed, food regimes clearly influence key life-history characteristics, of anchovy including summer growth, over-wintering condition and energy storage prior and during reproduction (batch and seasonal fecundity). Importantly, at low food densities, changes to intensity and timing (relative to reproductive season) of peak food availability has a greater influence on maturity rates, spawning intervals, and batch and seasonal fecundity than do changes of relatively high food $\left(>\sim 90 \mathrm{mg}\right.$ zooplankton $\left.\mathrm{m}^{-3}\right)$. In a 4-year (standard) DEB simulation, a 10\% higher food intake rendered notable positive changes to an individual's Fulton's condition index, total length, weight and particularly annual fecundity (by $5 \%, 7 \%, 30 \%$, and $47 \%$, respectively). Such magnitude changes also accounted for differences in age-at-first parturition (Fig. 4B and 5B) and spawning intervals. Interestingly, simulating changes in seasonality ( $a$ in the sinusoidal curve) demonstrated that anchovy occupying less variable feeding conditions have reduced growth rates, although due to energetic limitations and temperature cues, few differences were observed in fecundity patterns.

Comparing individual and population-level processes, we found that the sensitivity to short-term environmental scenarios on age-specific annual fecundity and population rates (r) were similar, as were the responses of $r$ to shorter (1-year) and longer (5-year) variation (Fig. 6). Specifically, seasonal fecundity for an age-1 individual (hatched on the 1 June) could be reduced by as much as $20 \%$ if, for one year, temperature or food supply is decreased by 4 or $18 \%$, respectively or if the plankton bloom occurred 3 weeks earlier (Fig. 6A). Changes to the timing of the zooplankton bloom also impacted anchovy life-cycle dynamics with seasonal fecundity being reduced by $19-25 \%$ if the zooplankton densities peaked a month earlier (March) than what is typically observed in the GoL (Fig. 6). In contrast, if the zooplankton maximum occurred later in the season, in May, fecundity rates are likely to be increased by up to $30 \%$ for an age- 1 individual and around $14-21 \%$ for individuals aged $>2$ years. Fecundity rates were more sensitive to food peaking earlier than later in the year, food being depleted and higher than lower temperatures (Fig. 6A).

In 10-year IBM simulations, which included a 5-year baseline run, projections showed that population growth rates could be reduced by as much as $15 \%$ (relative to that estimated under mean conditions) due to either a $0.8^{\circ} \mathrm{C}$ drop in temperature, a $18 \%\left(25 \mathrm{mg}\right.$ zooplankton $\left.\mathrm{m}^{-3}\right)$ depletion in food, a $30 \%$ increase in egg mortality rates, or an earlier (late-February) seasonal food availability peak (Fig. 6B). Furthermore, when we altered 
environmental conditions for 5-years, we observed that magnitude $( \pm 20 \%)$ changes in food and temperature drastically effected mean annual population growth rates with declines in each factor having a greater impact (17.6 and 58.4\%, respectively) than an equivalent increase (9.2 and 48.1\%, respectively). At an $S S T_{\text {mean }}$ higher than $22^{\circ} \mathrm{C}$, egg and larvae survival rates were decreased due to forced mortality of eggs hatched in $>26^{\circ} \mathrm{C}$ (lethal threshold set) and also due to starvation, as those hatched in late Autumn and winter (outside the spring plankton bloom) did not have enough energy to sustain high growth and maintenance rates. For a similar reason, under the scenario of severely depleted food conditions $\left(>-20 \% \mathrm{X}_{\text {mean }}\right)$, cohorts hatched late in the season died from starvation during the yolk-sac larvae phase. As expected, population growth rates were largely influenced by magnitude changes to yolk-sac and older larval mortality rates (Fig. 6) largely due to high standard mortality rates being used (Table 3). Consequently, population growth rates were more sensitive to varying larval mortality rates than eggs (Fig. 6). Lastly, in a test where all older (>age-2) individuals from the stock were removed, population growth rates under standard GoL conditions only declined by $7 \%$ (not shown), emphasizing the importance of the early life-stages.

\section{DISCUSSION}

Small forage fish (family Clupeidae) such as anchovy are well known for their high sensitivity to environmental factors due to their flexible life histories, short lifespan, high mobility and growth rates (Martín et al. 2008; Palomera et al. 2007). In view of the need to better understand the interplay between environmental conditions and life-cycle dynamics of European anchovy, we offer a generic, mechanistic and bioenergeticallysound, individual-based modelling (IBM) approach. Working within the framework of Dynamic Energy Budget theory (Kooijman, 2010), our IBM proved to be a flexible tool that integrates complex and dynamic interactions between external factors and anchovy physiological characteristics and vital (growth and reproduction) rates. Through our twofold modelling approach, we were able to observe that a population size and structure emerge from processes acting at the individual level. For example, with the use of the stagestructured population IBM we observed that anchovy life history clearly depends on an individual's hatching date. In relation to this, it is evident that the growth during the first-year of life is particularly sensitive to temperature while recruitment (adult spawning season) relies on spring feeding conditions and summer temperatures (Fig. 4). Using scenarios (Section 2.5) as plausible (present or predicted) environmental conditions experienced by anchovies, this study presents a range of potential individual responses which we can link to changes in population growth rates.

Here we discuss separately (1) How the models performed by comparing our simulation results to modelindependent data collected in the field and/or presented in the literature, (2) How our scenario-based analyses were used to gain more insight into the sensitivity of the GoL anchovy population to environmental fluctuations, and (3) How this work can be utilized and improved in future studies with the collective aim of better understanding growth and recruitment fluctuations of anchovy populations.

\subsection{Model evaluation}

Under the current parameterization (Table 2) and standard GoL environmental conditions (Table 3 and Fig. 3), model simulations successfully captured ontogenetic and seasonal growth patterns, including positive growth in spring/summer and loss of mass in autumn/winter. Other bioenergetics models have also reproduced seasonality in European anchovy growth and reproduction in the Bay of Biscay (Pecquerie et al. 2009), Black Sea (Oguz et al. 2008) and Aegean Sea (Politikos et al. 2011) and together contribute to a greater understanding of life-cycle of the species.

Our models captured, in a mechanistic way, many life history parameters, such as age-at-maturity, spawning intervals, batch and seasonal fecundity, and the dynamics of condition, remarkably well (Fig. 4 and 5). Growth rates (Table 4) are comparable to those for European anchovy in the NW Mediterranean Sea (0.5 to $1.0 \mathrm{~mm} \mathrm{~d}^{-1}$; Cotano et al. 2008; Palomera et al. 1988, 2007; García et al. 1998, 2003; Sabatés et al. 2007; Roos et al. 2011). Energy density values $\left(23.3 \mathrm{KJ} \mathrm{g}^{-1}\right.$ on average) were within the range of that found in European anchovy from the GoL (20-24 kJ g ${ }^{-1}$ DW; Harmelin-Vivien et al. 2012) and the NE Mediterranean (22-26 kJ g ${ }^{-1} \mathrm{DW}$; Tirelli et al. 2006). Feeding rates as a proportion of body weight (Table 4) are well in agreement with current estimates based on stomach content analysis (2.5 - 4\%, Tudela and Palomera, 1995; Palomera et al. 2007; Plounevez and Champalbert, 2000). Likewise, model output on batch and seasonal fecundity rates (Table 5 and 
Fig. 4) are in reasonable agreement for European anchovy in the $\mathrm{GoL}\left(\mathrm{F}_{\text {batch }}=7023-8746\right.$ for an average female weight of $22 \mathrm{~g}$; Palomera et al. 2007). Projected number of annual batches (23 on average) was slightly lower than those assumed for stocks in the Eastern Mediterranean Sea (28, Politikos et al. 2011). Interspawning intervals at the peak of the season were within the range (3-5 days) given for anchovy in the Bay of Biscay (Motos, 1996) and estimated for the Aegean Sea (Somarakis, 2005). Lastly, we observed ontogenetic differences in the spawning duration and frequency which is in agreement with that observed in SW Spain (Milan, 1999).

Using the IBM we observed that relatively simple-appearing responses at the population level emerge from complex individual processes (Fig. 6). Specifically, the IBM efficiently captured and explicitly described interindividual growth and performance variability, caused by different hatching dates and thus, different environmental histories. High inter-individual variability in size-at-age, growth trajectories and age-specific fecundity rates, particularly in early life stages have been observed by numerous authors in the GoL (Pertierra and Lleonart, 1996; Bellido et al. 2000) and other anchovy populations (Basilone et al. 2003; Somarakis 2005). Our simulation results suggested that stocks are largely supported by young (age- 0 and age-1) anchovy and that individuals spawned late in the reproductive season (>September) contribute only marginally to the recruitment of the adult population. Such a finding is potentially very important for stock management, and should be further evaluated, perhaps by detailed analysis otoliths.

Although our IBM is able to quantify relative changes in asymptotic population growth rates and disentangle the impact of the timing and amplitude of both temperature and food conditions, there is a clear limit to exploring population dynamics, as we model exponential population growth and not density-dependent growth such as that used by Oguz et al (2008). Indeed, applying a quadratic model is favorable for exploring responses of population abundances to transitional changes in environmental conditions (Oguz et al 2008). Our study in contrast, chose to focus on relative changes in population growth which can be used as indicators of population sensitivity to bottom-up environmental scenarios.

\subsection{Scenario analysis}

Strong environmental-recruitment relationships have been observed in NW Mediterranean anchovy populations in which their fluctuations have been related to changes in temperature, surface chlorophyll-a, wind mixing and river runoff (Lloret et al. 2001, Basilone et al. 2006; Martín et al. 2008) and more recently to global climatic indices (Martín et al. 2012). It is promising that our bioenergetics model correctly depicted that anchovy show a high degree of physiological sensitivity to the environment, which can both drive and constrain life-history variation and population growth. Simulations of inter-annual (1-year) and multi-annual (4 and 5 year) variations in temperature, food availability and mortality rates demonstrate that due to their short-generational times, fluctuations in anchovy population size and structure can be observed rapidly between years. In fact, our IBM illustrated that a high proportion of anchovy biomass fluctuations in the GoL could be explained by environmental variability as has been suggested for other stocks (Sebatés et al. 2007).

Anchovy vital rates were most sensitive in our scenarios to magnitude changes of temperature due to its control over the timing and duration of the species reproductive cycle (Palomera et al. 2007) rather than comparable changes in food supply (density or timing) and early mortality rates (Fig. 6). Although the range of temperature scenarios chosen are representative of those predicted for the Mediterranean Sea and currently experienced over the entire distribution of European anchovy (West African coast to Southern North Sea), it should be noted that annual temperature cycles (in the GoL and elsewhere) display much less spatial and temporal short-term variability than do the dynamics of anchovy food (plankton) (Fig. 3). Furthermore, although it would be rare that mean annual temperatures change more than $10 \%\left(1.9^{\circ} \mathrm{C} \mathrm{SST}\right)$ between years, high annual variations in plankton densities $\left(>10 \%=>0.035 \mathrm{mg}\right.$ chl-a $\mathrm{m}^{-3}$ or $12.5 \mathrm{mg}$ zooplankton $\left.\mathrm{m}^{-3}\right)$ are recorded often (e.g. Gaudy et al. 2003; Espinasse 2012 and this study, Fig. 3). Likewise, large annual variations in the timing (phase shift) of bloom events are observed, including those associated with the strong E-W and N-S spatial gradients in the GoL (Marty and Chiaverini, 2002). With this in mind, it is also important to note that food regimes predominantly influence adult summer growth rates and over-wintering condition (Fig. 4A-C), energy storage prior reproduction and maternal energy investment. Consequently, anchovy production is negatively affected by lower than averaged food resources or an early plankton bloom 
relative to the spawning season. In contrast, a $10 \%$ increase in the food amplitude (seasonality) was shown to positively affect growth potential, but have limited influence of lifetime fecundity, meaning that at these (rather high) mean food conditions, small fluctuations in peak intensity are more important than peak intensity. We expect that this would differ if lower mean food density values and/or in highly $( \pm 20 \%)$ seasonal conditions were simulated, as discussed in detail by Muller and Nisbet (2000). Food availability was an equally important index for simulated anchovy growth in the Aegean Sea population (Politikos et al. 2011) and was the dominant hypothesis put forward to explain a recent increase of the anchovy population in the North Sea (Petitgas et al. 2012).

Anchovy biomass estimates in the GoL have fluctuated enormously between 1995 to 2010 with annual biomass increasing as high as $69 \%$ between 2000 and 2001 and then decreasing 54\% the consecutive year in 2002 (Pelmed survey data, Ifremer). In a 10-year IBM simulation, we investigated short- (1-year) and long- (5-year) term population growth by altering environmental conditions for 5-years after a 5-year baseline run. Altering food conditions by $\pm 20 \%$ changed the population growth rates by $7.6-9.6 \%$ and biomass estimates by as much as $9-18 \%$ over just 1 -year. Two very interesting findings arose from our scenario-based simulations; (1) a decline in either temperature or food has a much greater impact on population performance than did an equivalent proportional increase, and (2) Similar population growth rates are observed when magnitude changes occur over a very short (1-year) period and a slightly longer, multi-annual (5-year) period (Fig. 5). This, along with the fact that removal of older individuals had no effect on population growth, clearly demonstrates the importance of the vital rates of age- 1 individuals. These results also confirm findings of Koons et al. (2005) who demonstrated that population dynamics in short-lived species were more resilient to departures from the stable state than slow growing, low reproduction rate species.

\subsection{Future applications and model improvement}

We provided a processes-based model framework, based on the Dynamic Energy Budget theory that can help understand how anchovy population dynamics emerge from processes acting at the individual level. It is promising that our models can reproduce temporal (seasonal and annual) trends in demographic vital rates and quantify relationships between environmental factors, fecundity rates and the rate of population change $(r)$ which are important for determining effective strategies for population management. This work is a first step that needs to be followed by others in order to obtain a better understanding of the growth and recruitment fluctuations of European anchovy populations. In its current form, our model framework (bioenergetics model separately or as an IBM) could have several applications. Firstly, the IBM could be applied to other populations/ecosystems and certain modules (e.g. reproduction) could be incorporated into similar models for other small pelagic and foraging species such as sardine, sprat and mackerel. Of current topical interest is the coupling of individual-based bioenergetics models to end-to-end ecosystem models (e.g. Megrey et al. 2007) to bridge the gap between the ends of the food web and examine density-dependent and higher-level processes. Likewise, coupling our DEB model to a larvae dispersal model (e.g. Lett et al. 2008; Ospina-Alvarez et al. 2012) would prove helpful to examine environmental-based recruitment hypotheses and connectivity issues. Furthermore, due to the ability to supply a mechanistic framework in which to understand food/compound intake, metabolism and elimination, our DEB model can be effectively coupled with toxicokinetic models in which to investigate contaminant accumulation (e.g. PCB's). Such work has proved fruitful for European hake in the GoL (Bodiguel et al. 2009) and is currently being undertaken for the European anchovy to be published elsewhere.

As with any model, ours has several limitations in its current ability to hindcast past and project future changes in anchovy stock dynamics. This primarily stems from (1) difficulties in estimating DEB and feeding related parameters, due to lack of published data on anchovy (2) a lack of spatio-temporal and size-specific zooplankton data, and (3) a lack of prey and predator density-dependent mechanisms. Typically, the improvement of DEB parameters is achieved by laboratory based experiments to obtain better estimates of metabolic rates and processes (ie. assimilation rates, efficiency and allocation rules, oxygen consumption rates, etc.); this however, is not very practical for anchovy. Feeding parameters could essentially be better estimated using knowledge of stomach content data or enzyme based and other biochemical indices of feeding rates. In regards to prey information, lower-trophic biogeochemical models are still in the development stage of being implemented to the GoL (e.g. the Eco3M framework; Baklouti et al. 2006). Once sufficiently validated and available, such a model may supply more realistic feeding conditions and in three-dimensional space as have 
been done for other anchovy populations (Pecquerie et al. 2009; Politikos et al. 2011). Such a model would also permit the inclusion of diel and intermittent feeding cycles and an environmental stochasticity. Once these factors are considered, we believe that the IBM model presented here will have sufficient forecasting power to provide useful information to fishery and ecosystem resource managers. This includes improving our current ability to understand and forecast the short and long-term effects of climate change on small pelagic fish dynamics.

\section{Acknowledgments}

We are grateful to Isabel Palomera and Andrés Ospina-Alvarez (CSIC institute, Barcelona), Jean-Hervé Bourdeix and Blandine Brisset (Ifremer, Sète) and fishermen (AMOP) who collected and processed the biological data used in this study. We thank Nathalie Bodin (IRD, Sète) and Catherine Muncshy (Ifremer, Nantes) for unpublished data on anchovy lipid dynamics and Boris Espinasse and Francois Carlotti (MIO, Marseille) for vital information on zooplankton dynamics in the Gulf of Lions. Pierre Garreau (Ifremer, Brest) is thanked for supplying output from the 3D hydrodynamic model MARS. Ignacio Catalán, Brian Fath and an anonymous reviewer helped strengthened this papers contents. This research was conducted within the project COSTAS (ANR CES AA-PPPP-007).

\section{References}

Antoine, D., André, J.M., Morel, A., 1996. Oceanic primary production 2. Estimation at global scale from satellite (coastal zone color scanner) chlorophyll. Global Biogeochem. Cycles. 10, 57-69.

Augustine, S., Litvak, M.K., Kooijman, S.A.L.M., 2011. Stochastic feeding of fish larvae and their metabolic handling of starvation. J. Sea Res. 66(4),411-418.

Baklouti, M., Faure, V., Pawlowski, L., Sciandra, A., 2006. Investigation and sensitivity analysis of a mechanistic phytoplankton model implemented in a new modular numerical tool (Eco3M) dedicated to biogeochemical modelling. Prog. Oceanogr. 71(1), 34-58.

Basilone, G., Guisande, C., Patti, B., Mazzola, S., Cuttitta, A., Bonanno, A., Vergara, A.R., et al., 2006. Effect of habitat conditions on reproduction of the European anchovy (Engraulis encrasicolus) in the Strait of Sicily. Fish Oceanogr. 15(4), 271-280.

Bellido, J;M,. Pierce, G.J., Romero, J.L., Millan, M., 2000. Use of frequency analysis methods to estimate growth of anchovy (Engraulis encrasicolus L. 1758) in the Gulf of Cadiz (SW Spain). Fish. Res. 48, 107 115.

Bernard, I., de Kermoysan, G., \& Pouvreau, S. 2011. Effect of phytoplankton and temperature on the reproduction of the Pacific oyster Crassostrea gigas: Investigation through DEB theory. J. Sea Res. 66(4),349-360.

Bodiguel, X., Olivier, M., Capucine, M., François, R., Le Guellec, A., Loizeau, V., 2009. A dynamic and mechanistic model of PCB bioaccumulation in the European hake (Merluccius merluccius). J. Sea Res. 62, 124-134.

Costalago, D., Navarro, J., Álvarez-Calleja, I., Palomera, I., 2012. Ontogenetic and seasonal changes in the feeding habits and trophic levels of two small pelagic fish species. Mar. Ecol. Prog. Ser. 460, 169-181.

Costalago, D., Tecchio, S., Palomera, I., Álvarez-Calleja, I., Ospina-Álvarez, A., Raicevich, S., 2011. Ecological understanding for fishery management: Condition and growth of anchovy late larvae during different seasons in the Northwestern Mediterranean. Estuar. Coast Shelf Sci. 93(4), 350-358.

Cotano, U., Irigoien, X., Etxebeste, E., Alvarez, P., Zarauz, L., Mader, J., Ferrer, L., 2008. Distribution, growth and survival of anchovy larvae (Engraulis encrasicolus L.) in relation to hydrodynamic and trophic environment in the Bay of Biscay. J. Plankton Res. 30(4), 467-481.

Espinasse, B., 2012. Distribution and size structure of zooplankton communities in two coastal ecosystems. Study of impact of physical and trophic factors on zooplankton spatial distribution and size spectrum. $\mathrm{PhD}$ Thesis. Université de Marseille, France

Estrada, M., 1985. Primary production at the deep chlorophyll maximum in the western Mediterranean. In: Gibbs, P.E. (Eds.), Proceeding of the 19th European Marine Biology Symposium. Cambridge University Press, pp.109-121.

García, A., Cortés, D., Ramírez, T., Giráldez, A., Carpena, A., 2003. Contribution of larval growth rate variability to the recruitment of the Bay of Málaga anchovy (SW Mediterranean) during the 2000-2001 spawning seasons. Sci. Mar., 67(4), 477-490. 
García, A., Cortés, D.,Ramírez, T., 1998. Daily larval growth and RNA and DNA content of the NW Mediterranean anchovy Engraulis encrasicolus and their relations to the environment. Mar. Ecol. Progr. Ser. 166, 237-245.

García, A., Palomera, I., 1996. Anchovy early life history and its relation to its surrounding environment in the Western Mediterranean Basin. Sci. Mar. 60,155-166.

Gaudy, R., Youssara, F., Diaz, F., Raimbault, P., 2003. Biomass, metabolism and nutrition of zooplankton in the Gulf of Lions (NW Mediterranean). Oceanol. Acta, 26,357-372.

Harmelin-Vivien, M., Mahé, K., Bodiguel, X., Mellon-Duval, C., 2012. Possible link between prey quality, condition and growth of juvenile hake (Merluccius merluccius) in the Gulf of Lions (NW Mediterranean). Cybium, 36(2), 335-348.

Hunter, J.R., Macewicz. B.J., 1985. Measurement of spawning frequency in multiple spawning fishes. In: Lasker, R., (Eds.), An Egg Production Method for Estimating Spawning Biomass of Pelagic Fish: Application to the Northern Anchovy, Engraulis mordax. NOAA Tech. Rep. NMFS 36, pp. 79-93.

James, A.G., Probyn, T., Seiderer, L.J., 1989. Nitrogen excretion and absorption efficiencies of the Cape anchovy Engraulis capensis Gilchrist fed upon a variety of plankton diets. J Exp Mar Biol Ecol 131, 101124.Jusup, M., Klanjscek, T., Matsuda, H., Kooijman, S.A.L.M., 2011. A full lifecycle bioenergetic model for Bluefin Tuna. PLoS ONE 6(7), e21903.

Katara, I., Pierce, G. J., Illian, J., Scott, B.E., 2011. Environmental drivers of the anchovy/sardine complex in the Eastern Mediterranean. Hydrobiologia, 670(1), 49-65.

Kaya, Y., Turan. H. (2008). Comparison of protein, lipid and fatty acids composition of anchovy (engraulis encrasicolus L. 1758) during the commercial catching season. J. Muscle Foods, 21, 474-483.

Kooijman, S.A.L.M., 2010. Dynamic energy budgets theory for metabolic organization, $3^{\text {rd }}$ Edition Cambridge University Press.

Kooijman, S.A.L.M., Sousa, T., Pecquerie, L., Van der Meer, J., Jager, T., 2008. From food dependent statistics to metabolic parameters, a practical guide to the use of dynamic energy budget theory. Biol. Rev. 83, 533552.

Koons, D.N., Grand, J.B., Zinner, B., Rockwell, R.F., 2005. Transient population dynamics: relations to life history and initial population state. Ecol. Model. 185, 283-297.

Lazure, P., Dumas, F., 2008. An external-internal mode coupling for a 3D hydrodynamical model for applications at regional scale (MARS). Adv. Water Resources 31, 233-250.

Lazzari, P., Solidoro, C., Ibello, V., Salon, S., Teruzzi, a., Béranger, K., Colella, S., et al. 2011. Seasonal and inter-annual variability of plankton chlorophyll and primary production in the Mediterranean Sea: a modelling approach. Biogeosci. Discussions 8(3), 5379-5422.

Lett, C., Verley, P., Mullon, C., Parada, C., Brochier, T., Penven, P., Blanke, B., 2008. A Lagrangian tool for modelling ichthyoplankton dynamics. Environ. Model. Software 23, 1210-1214.

Lika, K., Kearney, M.R., Freitas, V., van der Veer, H.W., van der Meer, J., Wijsman, J.W.M., Pecquerie, L., Kooijman, S.A.L.M., 2011. The "covariation method" for estimating the parameters of the standard Dynamic Energy Budget model I: Philosophy and approach. J. Sea Res. 66, 270-277.

Lionello, P., Malanotte-Rizzoli, P., Boscolo, R., 2006. Mediterranean climate variability. Elsevier, Amsterdam, Neatherlands.

Lloret, J., J. Lleonart, I. Sole' J. M. Fromentin, 2001. Fluctuations of landings and environmental conditions in the north-western Mediterranean Sea. Fish Oceanogr. 10, 33-50.

Lluch-Belda, D., Crawford, R.J.M., Kawasaki, T., MacCall, A.D., Parrish, R.H., Schwartzlose, R.A., Smith, P.E., 1989. World-wide fluctuations of sardine and anchovy stocks: the regime problem. S. Afr. J. mar. Sci. 8, 195-205.

Martín, P., Bahamon, N., Sabatés, A., Maynou, F., Sanchez, P., Demestre, M., 2008. European anchovy (Engraulis encrasicolus) landings and environmental conditions on the Catalan Coast (NW Mediterranean) during 2000-2005

Martín, P., Sabatés, A., Lloret, J., Martin-Vide, J., 2012. Climate modulation of fish populations: the role of the Western Mediterranean Oscillation (WeMO) in sardine (Sardina pilchardus) and anchovy (Engraulis encrasicolus) production in the north-western Mediterranean. Climatic Change 110(3-4), 925-939.

Marty, J.C., Chiaverini, J., 2002. Seasonal and interannual variations in phytoplankton production at DYFAMED time-series station, northwestern Mediterranean Sea, Deep-Sea Res. II, Top. Stud. Oceanogr. 49, 2017-2030. 
Megrey B. A., Rose, K. A., Klumb, R. A, Hay, D. E., Werner, F. E., Eslinger, D. L. Smith, S. L., 2007. A bioenergetics-based population dynamics model of Pacific herring (Clupea harengus pallasi) coupled to a lower trophic level nutrient-phytoplankton-zooplankton model: Description, calibration, and sensitivity analysis. Ecol. Model. 202, 144-64.

Millàn, M., 1999. Reproductive characteristics and condition status of anchovy Engraulis encrasicolus L. from the Bay of Cadiz (SW Spain). Fisheries Res. 41, 73-86.

Motos, L., 1996. Reproductive biology and fecundity of the Bay of Biscay anchovy population (Engraulis encrasicolus L.). Sci. Mar. 60(2), 195-207.

Muller, E. B., Nisbet, R. M., 2000. Survival and production in variable resource environments. Bull. Math. Biol. 62(6), 1163-89.

Nicolle, A., Garreau, P., \& Liorzou, B. 2009. Modelling for anchovy recruitment studies in the Gulf of Lions (Western Mediterranean Sea). Ocean Dyn. 59(6), 953-968.

Oguz, T., Salihoglu, B., Fach, B., 2008. A coupled plankton-anchovy population dynamics model assessing nonlinear controls of anchovy and gelatinous biomass in the Black Sea. Mar. Ecol. Prog. Ser. 369, 229256.

Ospina-Álvarez, A., Palomera, I., Parada, C., 2011. Changes in egg buoyancy during development and its effects on the vertical distribution of anchovy eggs. Fish. Res.. 117, 86-95.

Ospina-Alvarez, A., Parada, C.E., Palomera, I., 2012. Vertical migration effects on the dispersion and recruitment of European anchovy larvae: from spawning to nursery areas. Ecol. Mod. 231, 65-79.

Palomera, I., 1992. Spawning of anchovy Engraulis encrasicolus in the North Western Mediterranean relative to hydrographic features in the region. Mar. Ecol. Prog. Ser. 79, 215-223.

Palomera, I., Lleonart, J., 1989. Field mortality estimates of anchovy larvae, Engraulis encrasicolus, in the western Mediterranean. J. Fish Biol. 35(A), 133-138.

Palomera, I., Morales-Nin, B., Lleonart, J., 1988. Larval growth of anchovy, Engraulis encrasicolus, in the Western Mediterranean. Mar. Biol. 99, 283-291.

Palomera, I., Olivar, M. P., Salat, J., Sabatés, A., Coll, M., Garc1'a, A., Morales-Nin, B., 2007. Small pelagic fish in the NW Mediterranean Sea: an ecological review. Prog. Oceanogr. 73, 377-396.

Palomera, I., Recasens, L., Mol, B., Libori, P., 2009. Spawning stock biomass of the North Western Mediterranean anchovy in 2007 and 2008 GSA 6 and GSA 7. Biomass, (ICM), 37-49.

Pecquerie, L., Petitgas, P., Kooijman, S.A.L.M., 2009. Modeling fish growth and reproduction in the context of the Dynamic Energy Budget theory to predict environmental impact on anchovy spawning duration. J. Sea Res. 62, 93-105.

Pertierra, J. P. Lleonart, J.,1996. NW Mediterranean anchovy fisheries. Sci. Mar. 60, 257-267.

Pertierra, J. P., Lleonart, J., Lo, N. C. H., 1997. Application of a stage-specific matrix model and length-cohort based analysis to assess the anchovy fishery in Catalan coastal waters (NW Mediterranean Sea). Fish. Res. $30,127-137$.

Petitgas, P., Alheit, J., Peck, M., Raab, K., Irigoien, X., Huret, M., van der Kooij, J., et al. 2012. Anchovy population expansion in the North Sea. Mar. Ecol. Progr. Ser. 444, 1-13.

Pitta, P., Giannakourou, A., and Christaki, U., 2001. Planktonic ciliates in the oligotrophic Mediterranean Sea: longitudinal trends of standing stocks, distributions and analysis of food vacuole contents. Aquat. Microb Ecol. 24, 297-311.

Plounevez, S. Champalbert, H., 2000. Diet, feeding behaviour and trophic activity of the anchovy (Engraulis encrasicolus L.) in the Gulf of Lions (Mediterranean Sea). Oceanografica Acta 23, 175-192.

Politikos, D., Triantafyllou, G., Petihakis, G., Tsiaras, K., Somarakis, S., Ito, S., Megrey, B.A., 2011. Application of a bioenergetics growth model for European anchovy (Engraulis encrasicolus) linked with a lower trophic level ecosystem model. Hydrobiologia 670, 141-163.

Razouls, C. Kouwenberg, J.H.M., 1993. Spatial distribution and seasonal variation of mesozooplankton biomass in the Gulf of Lions (northwestern Mediterranean). Oceanol. Acta 16, 393-401.

Regner, J. H., 1996. Effects of environmental changes on early stages and reproduction of anchovy in the Adriatic Sea. Sci. Mar. 60, 167-177.

Roos, D., Bigot, J.L., Le Corre, G., Bourdeix, J.H., 2011. Diagnostic des populations d'Anchois et de Sardine du Golfe du Lion. Rapport d'avancement, May 2010. Partenariat scientifique Ifremer/Amop pour une gestion de la ressource en petits pélagiques. 
Rossi, S., Sebatés, A., Latasa, M., Reyes, E., 2006. Lipid biomarkers and trophic linkages between phytoplankton, zooplankton and anchovy (Engraulis encrasicolus) larvae in the NW Mediterranean. J. Plankton Res. 28(6), 551-562.

Sabatés, A., Salat, J., Palomera, I., Emelianov, M., Fernández De Puelles, M. L., Olivar, M. P., 2007. Advection of anchovy (Engraulis encrasicolus) larvae along the Catalan continental slope (NW Mediterranean). Fish. Oceanogr. 16(2), 130-141.

Siokou-Frangou. I., 1996. Zooplankton annual cycle in a Mediterranean coastal area. J. Plankton Res.18, 203223.

Somarakis, S., 1999. Ichthyoplankton of the Northeastern Aegean Sea with Emphasis on Anchovy Engraulis encrasicolus (Linnaeus, 1758) (June 1993, 1994, 1995, 1996). University of Crete.

Somarakis, S., 2005. Marked interannual differences in reproductive parameters and daily egg production of anchovy in the northern Aegean Sea. Belg. J. Zool. 135,247-252.

Somarakis, S., Palomera, I., Garciá, A., Quintanilla, L., Koutsikopoulos, C., Uriarte A., Motos, L., 2004. Daily egg production of anchovy in European waters. ICES J. Mar. Sci. 61,944-958.

Tirelli, V., Borme, D., Tulli, F., Cigar, M., Fonda Umani, S., Brandt, S. B., 2006. Energy density of anchovy Engraulis encrasicolus L. in the Adriatic sea. J. Fish Biol. 68, 982-989.

Tudela, S., Palomera, I., 1995. Diel feeding intensity and daily ration in the anchovy Engraulis encrasicolus in the Northwest Mediterranean sea during the spawning period. Mar. Ecol. Prog. Ser. 129, 55-61.

Tudela, S., Palomera, I., 1997. Trophic ecology of European anchovy Engraulis encrasicolus in the Catalan Sea (Northwest Mediterranean). Mar. Ecol. Prog. Ser. 160, 121-134.

Valdés, E.S., 1993. The energetics and evolution of intraspecific predation (egg cannibalism) in the anchovy Engraulis capensis. Mar. Biol. 115, 301-308.

Van der Veer, H.W., Kooijman, S.A.L.M., Van der Meer, J., 2001. Intra- and interspecies comparison of energy flow in North Atlantic flatfish species by means of dynamic energy budgets. J. Sea Res. 45, 303320.

Vandromme, P., Stemmann, L., Berline, L., Gasparini, S., Mousseau, L., Prejger, F., Passafiume, O., et al. 2010. Zooplankton communities fluctuations from 1995 to 2005 in the Bay of Villefranche-sur-Mer (Northern Ligurian Sea, France). Biogeosci. Discussions 7(6), 9175-9217. 


\section{TABLES AND FIGURES}
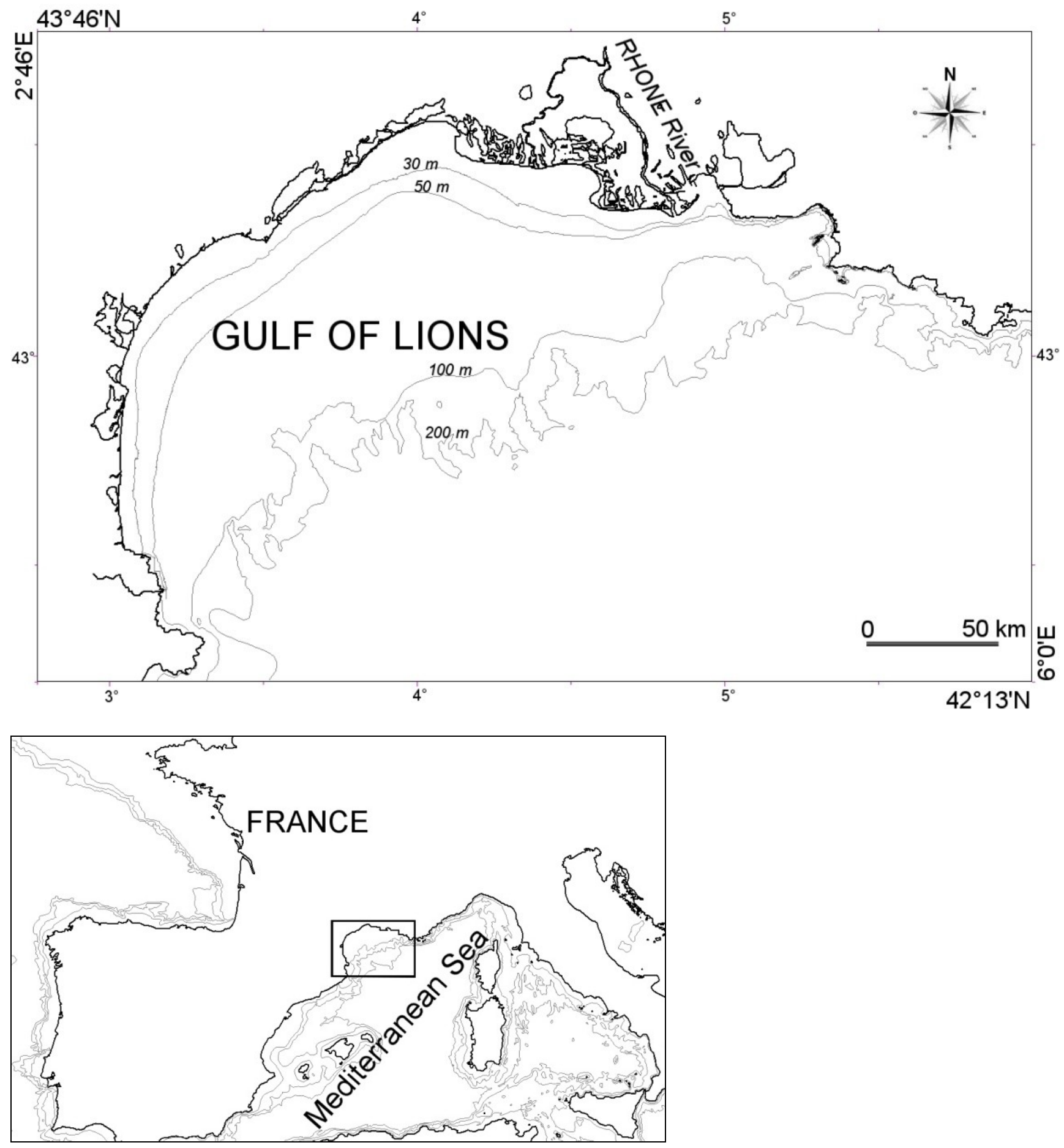

Figure 1. Figure of the study area, Gulf of Lion (GoL), North West Mediterranean Sea. 


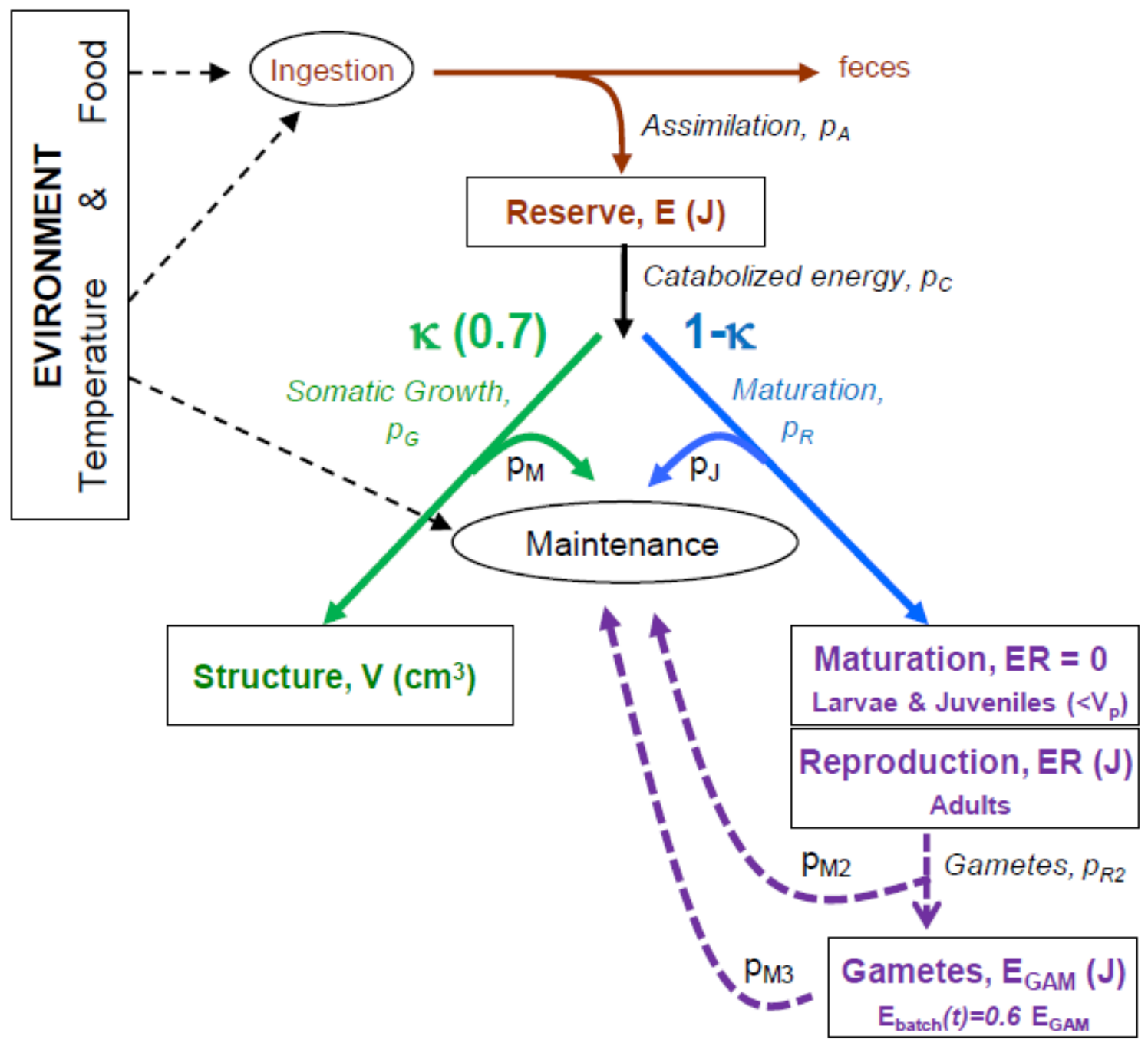

Figure 2. Conceptual diagram of the dynamic energy budget (DEB) of an individual. 
A
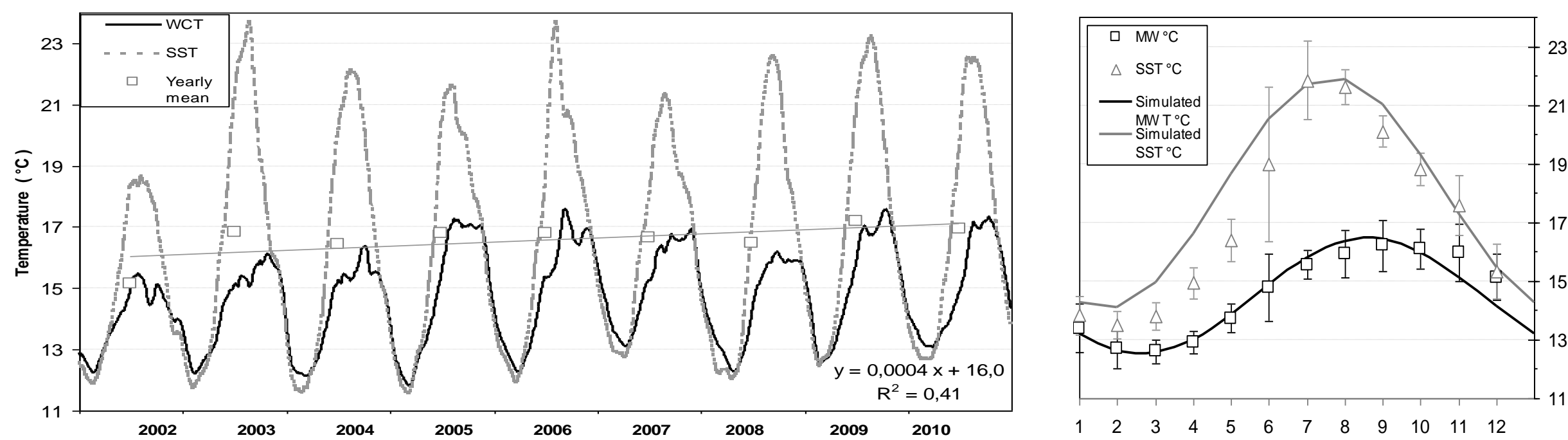

B
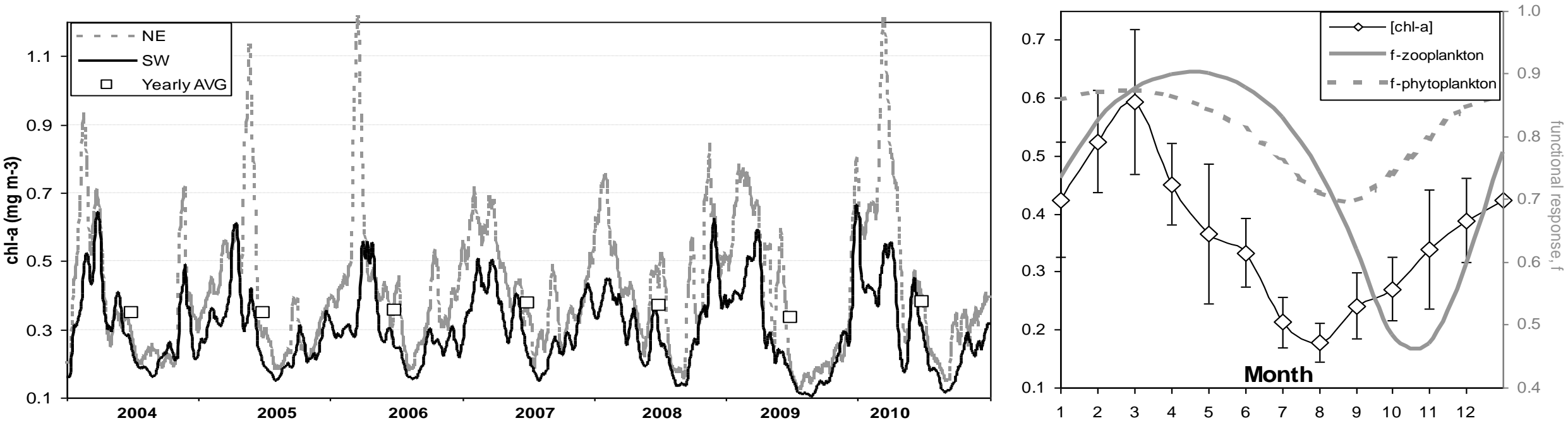

Figure 3. Patterns of environmental forcing in the Gulf of Lion (GoL, NW Mediterranean; Fig. 1) and sinusoidal functions used for model simulations, including: A) daily and mean monthly temperatures for 2002- 2010 with which we simulate sea surface temperature (SST) at $18 \pm 4^{\circ} \mathrm{C}$ and mid-water temperature (MWT) at $16 \pm 2{ }^{\circ} \mathrm{C}$, and (B) daily and mean monthly satellite-derived surface chlorophyll-a concentration for 2004-2010 witch were used to estimate the scaled functional response for larvae stages. On the time-series data plots, open squares represent mean annual SST and chl-a values and illustrate a mean annual increased of SST $\left(0.22{ }^{\circ} \mathrm{C} \mathrm{SST}\right.$ and $1.4^{\circ} \mathrm{C}$ over the 9-years) and high inter-annual variability (as high as $1.6^{\circ} \mathrm{C}(11 \%) \mathrm{SST}$ and $0.037(8 \%) \mathrm{mg}$ chl-a $\mathrm{m}^{3}$; respectively) using median annual values in the GoL. 

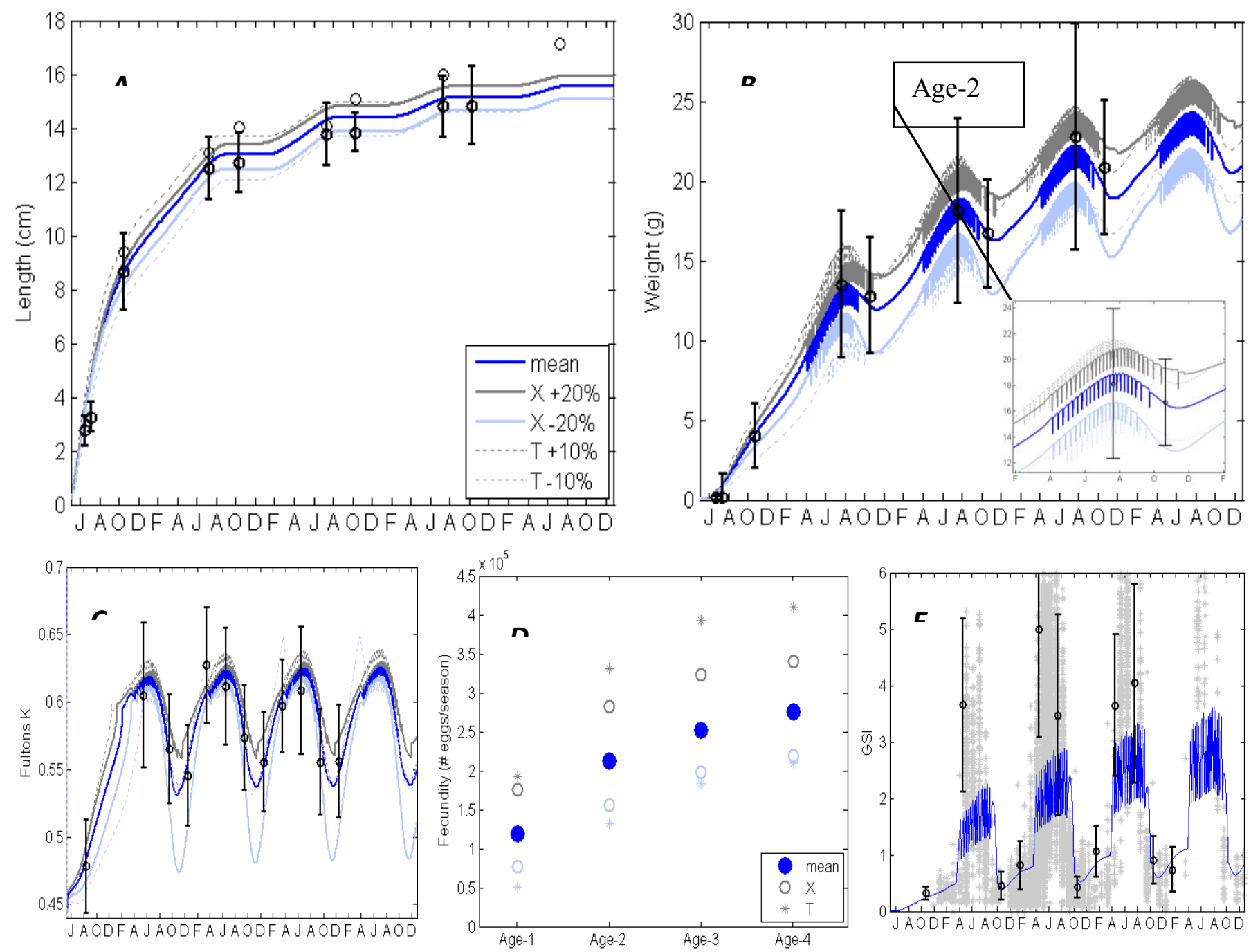

10 Figure 4. Four-year DEB model simulations of individuals (hatched on the $1^{\text {st }}$ June) under mean annual environmental conditions (dark blue) and magnitude changes of food $\left( \pm 20 \% \mathrm{X}_{\text {mean }}\right.$ and $\pm 10 \%$ $\left.12 \mathrm{~T}_{\text {mean }}\right) \mathrm{A}$ ) length-at-age, B) weight-at-age including a zoom of weight changes related to age-2 batchspawning events, C) Fulton's condition index, D) seasonal fecundity and E) gonad somatic index, GSI.

14 Error bars refer to mean \pm SD data collected in between 2007-2011 similarly to additional GSI data points (marked $*$ ) while additional length data points (marked o) represent the mean from samples collected between 1998-2006. 

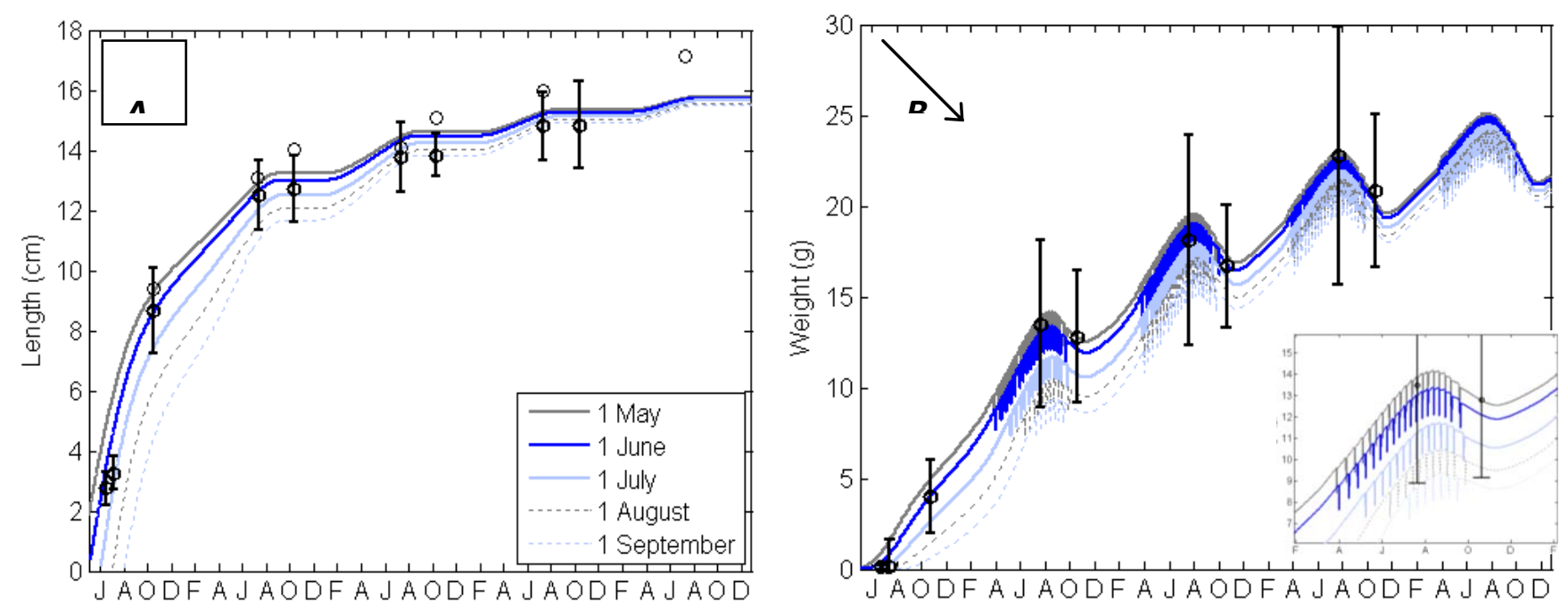

Figure 5. Four-year model simulations of individuals under mean annual environmental conditions 2 (dark blue) and different hatching dates ( $1^{\text {st }}$ May to $1^{\text {st }}$ September) for A) length-at-age and B) weight-at-age. Error bars refer to mean \pm SD data collected in between 2007-2011 while additional length data points (marked o) represent the mean from samples collected between 1998-2006. 
Magnitude changes of

TEMPERATURE
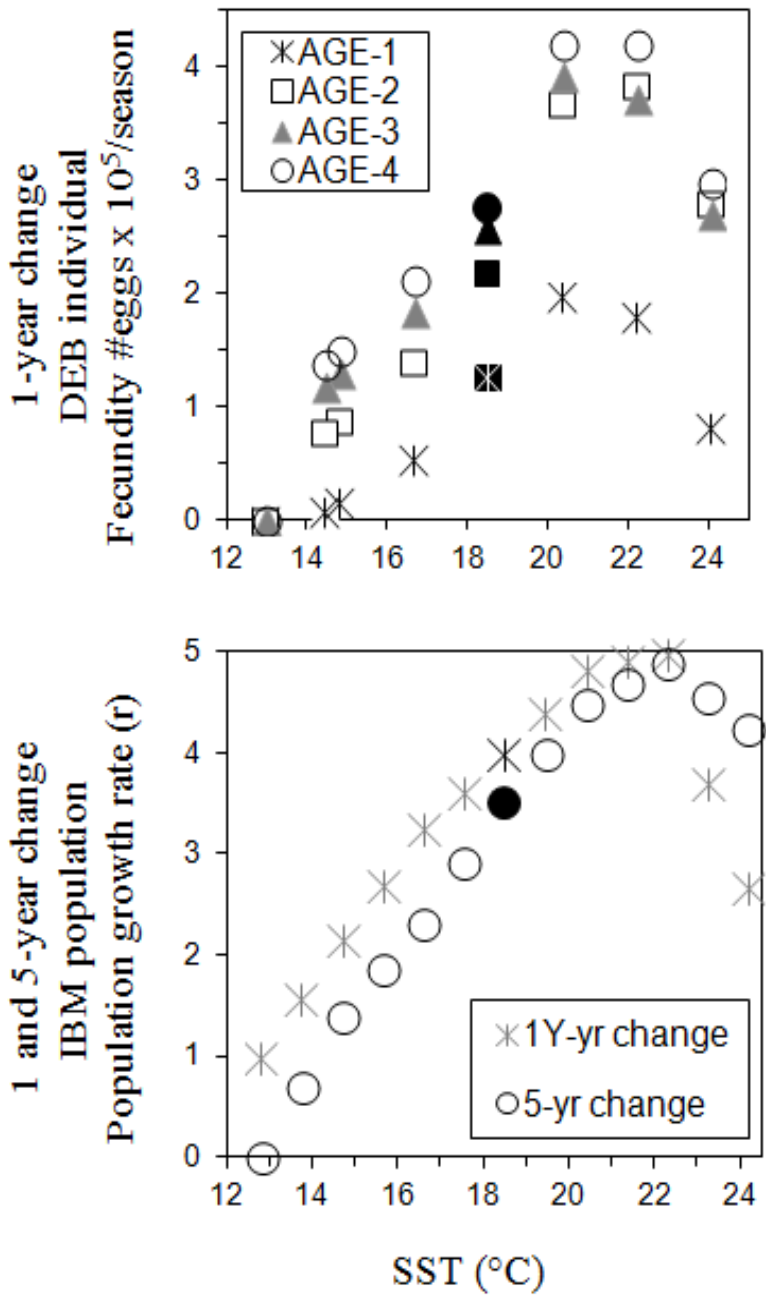

FOOD INTENSITY
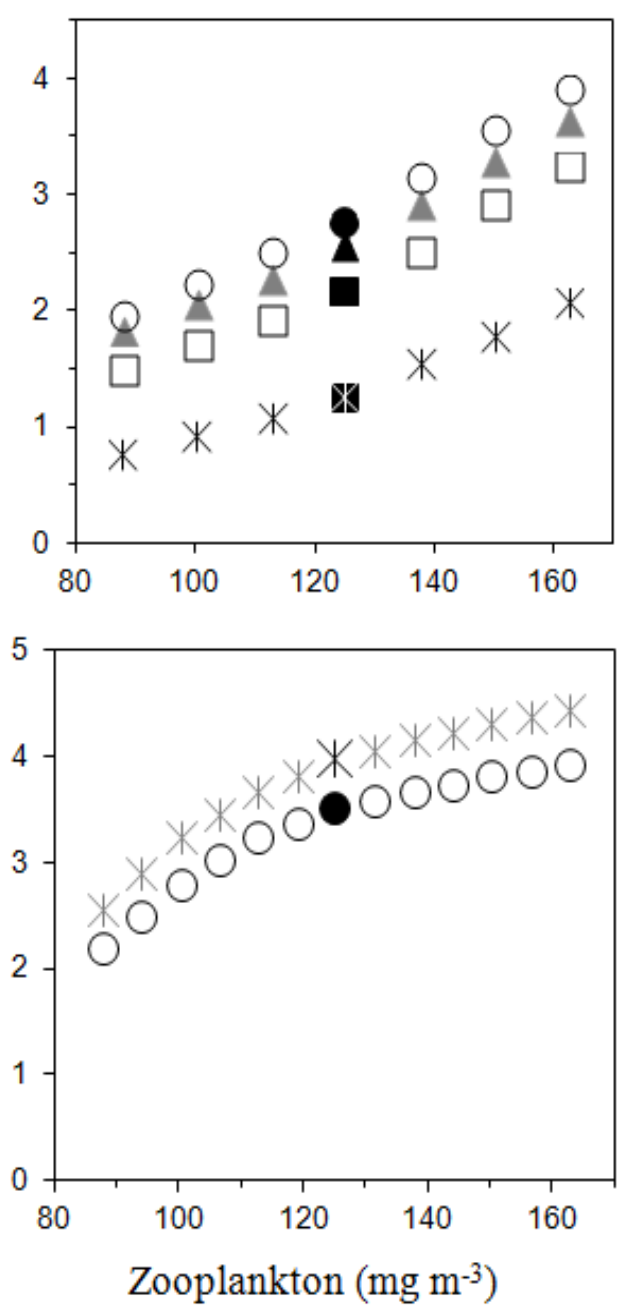

FOOD PEAK
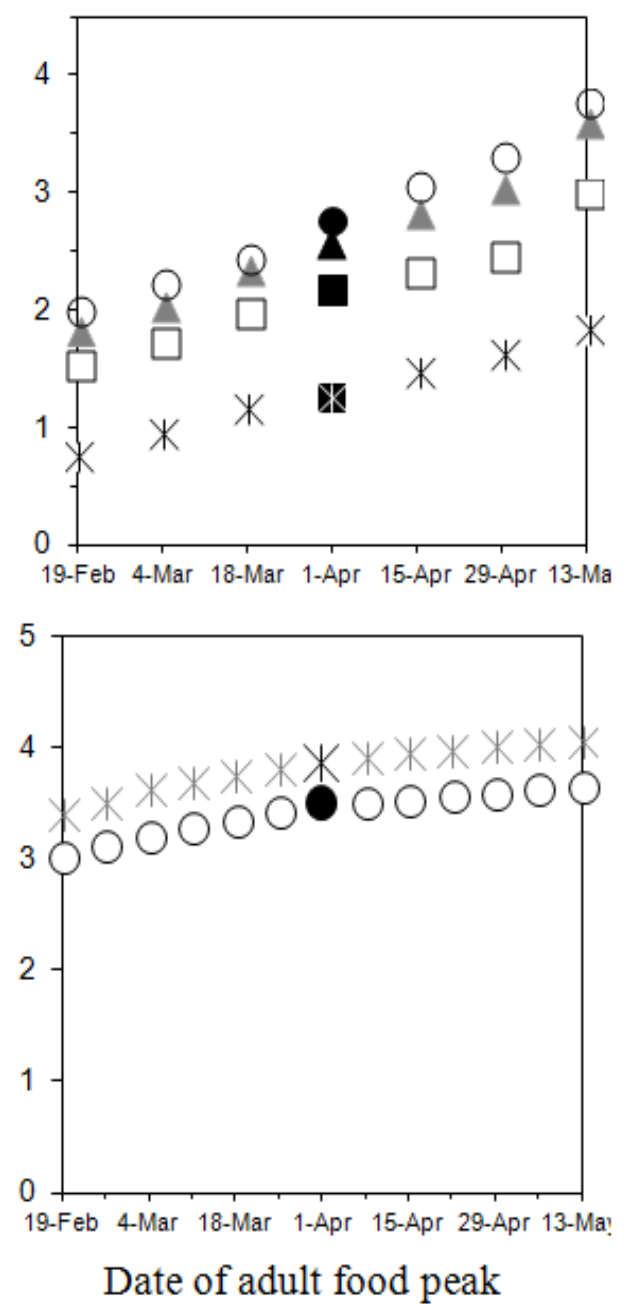

MORTALITY

NA

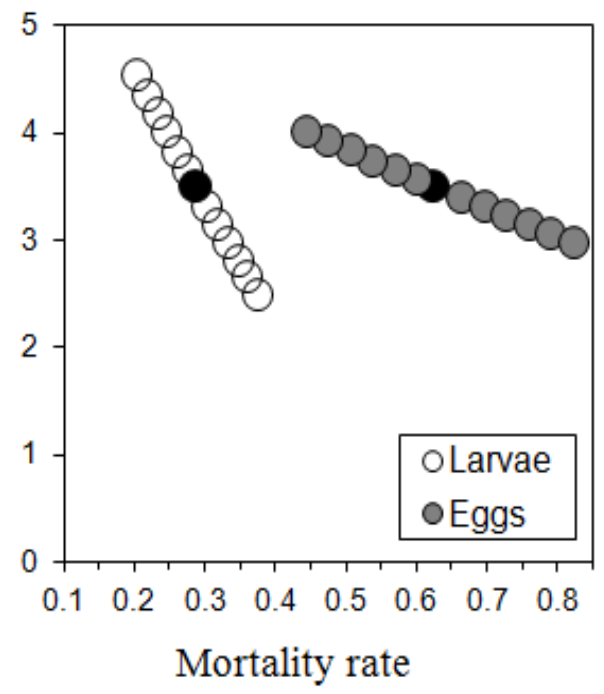

Figure 6. Response of individual seasonal fecundity and population (log-transformed biomass) growth of anchovy to relative (1 or 5-year long) magnitude changes of mean temperature, food availability, food phase shift and age-structured mortality rates. For each figure, data points represent simulations of one-at-atime 5\% (or 7-day) proportional increase or decrease of mean (solid black) values used in the standard run (given in Table 1). 
Table 1

Equations of the dynamic energy budget model fluxes, state variables and various output variables. All parameter values are listed in Table 2 and a conceptual diagram can be found in Fig 2 .

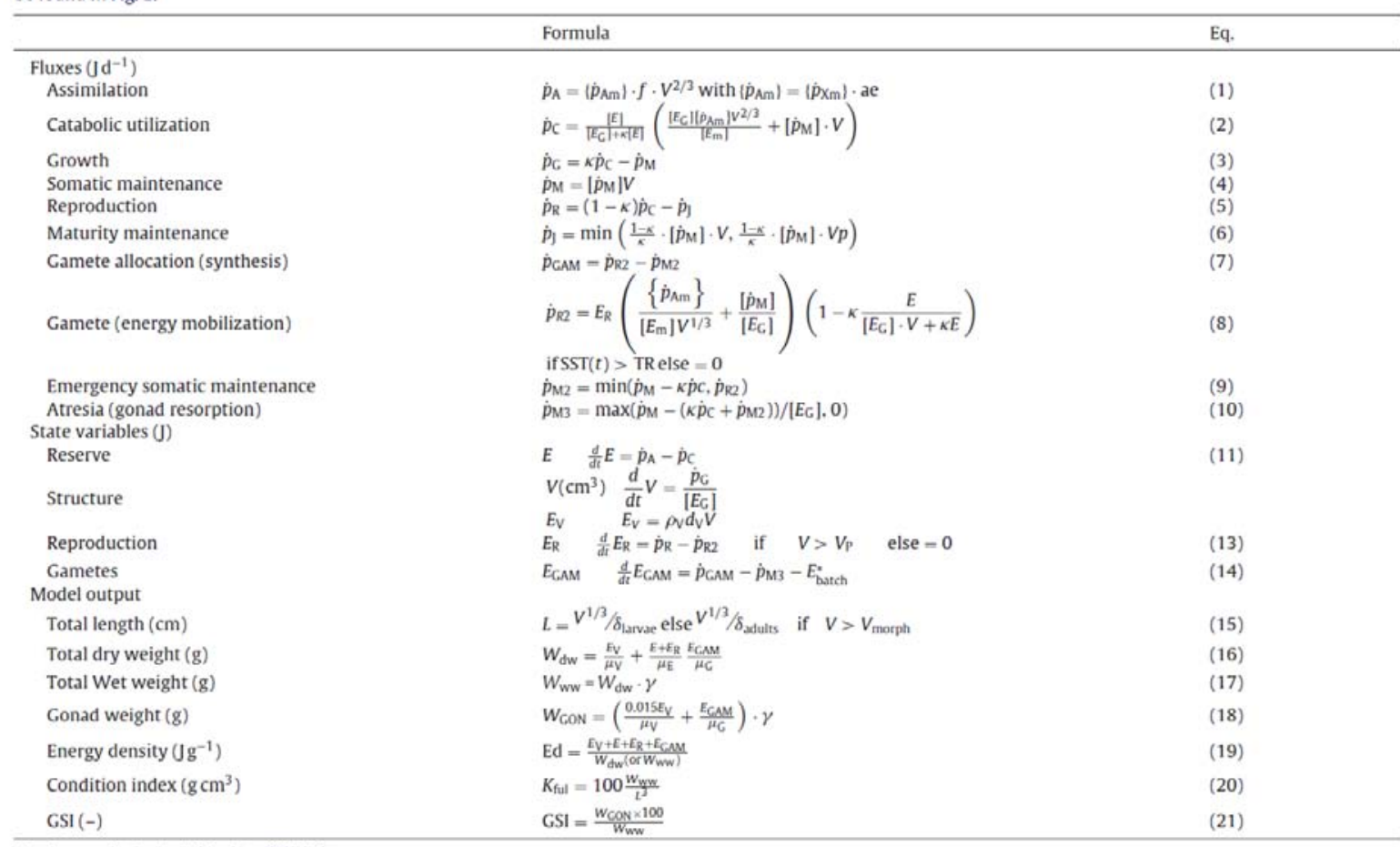

For $E_{\text {butch, }}$ refer to text (Section 2.2.1.1).

Table 2

List of DEB model parameter values used in this study for European anchovy in the Gulf of Lion, NW Mediterranean Sea including their percent sensitivity indices (SI) which were computed using mean length $(L)$ and weight $\left(W_{\text {ww }}\right)$ predictions after a 4-year simulation of an individual hatched on the 1st June.

\begin{tabular}{|c|c|c|c|c|c|}
\hline Primary DEB parameters ${ }^{2}$ & Symbol & Value & Units & $\mathrm{SI}(\mathrm{L})$ & $\mathrm{SI}(\mathrm{W})$ \\
\hline \multicolumn{6}{|l|}{ Feeding } \\
\hline Max. feeding rate & $\left\{\dot{p}_{\mathrm{Xm}}\right\}$ & 325 & $\mathrm{Jcm}^{-2} \mathrm{~d}^{-1}$ & 8.8 & 22.8 \\
\hline Assimilation efficiency & ae & 0.71 & - & 8.2 & 25.1 \\
\hline \multicolumn{6}{|l|}{ Energetic } \\
\hline Volume specific cost for structure & {$\left[E_{G}\right]$} & 4000 & $\mathrm{Jcm}^{-3}$ & 0.6 & 1.3 \\
\hline Max. storage density & {$\left[E_{\mathrm{m}}\right]$} & 2700 & $\mathrm{Jcm}^{-3}$ & 0.5 & 0.1 \\
\hline Volume specific maintenance costs & {$\left[\dot{p}_{M}\right]$} & 48 & $\mathrm{Jcm}^{-3} \mathrm{~d}^{-1}$ & 9.1 & 23.7 \\
\hline Fraction of energy allocated to growth & $\kappa$ & 0.7 & - & 9.8 & 24.5 \\
\hline \multicolumn{6}{|l|}{ Temperature } \\
\hline Temperature trigger for gamete production & TR & 16 & C SST & NA & NA \\
\hline Arrhenius temperature & TA & 9800 & $\mathrm{~K}$ & 0.1 & 0.1 \\
\hline \multicolumn{6}{|l|}{ Length conversions } \\
\hline Shape coefficient. Larvae & $\delta_{\text {Lavae }}$ & $0.154^{b}$ & - & 0.2 & NA \\
\hline Adult & $\delta_{\text {ydult }}$ & 0.169 & - & 5.6 & NA \\
\hline \multicolumn{6}{|l|}{ Mass conversions } \\
\hline Density of structure & $d V$ & 0.23 & $\mathrm{gcm}^{-3}$ & NA & 1.0 \\
\hline Energy density of $1 \mathrm{~g}$ structure & $\mu_{\mathrm{v}}$ & 19.9 & $\mathrm{KJg}^{-1}$ & NA & 0.9 \\
\hline Energy density of $1 \mathrm{~g}$ reserve & $\mu_{\mathrm{E}}$ & 35.2 & $\mathrm{KJ} \mathrm{g}^{-1}$ & NA & 0.6 \\
\hline Energy density of $1 \mathrm{~g}$ gametes & $\mu_{\mathrm{G}}$ & 33.4 & $\mathrm{KJ} \mathrm{g}^{-1}$ & NA & 0.1 \\
\hline$W_{\text {dw }}$ to $W_{\text {ww }}$ conversion & $\gamma$ & 4.1 & - & NA & 10.0 \\
\hline
\end{tabular}

Metabolic rates $\left(\mid \dot{p}_{\mathrm{Am}}\right)$ and $\left[\dot{p}_{\mathrm{M}} \mid\right)$ are given at the reference temperature, $T_{\mathrm{ref}}=289 \mathrm{~K}\left(=16^{\circ} \mathrm{C}\right)$. NA, not applicable.

a Represents parameters estimate by the simplex method in Debtool and input data detailed in Appendix 1.

b $\delta_{\text {lavar }}$ (if $\left.V<V_{\text {momph }}\right)=0.0025 V+\delta_{\text {lavrac }}$. 
Table 3. Life-stage specific variables for the standard Gulf of Lion, European anchovy DEB-IBM simulation, including size thresholds $\left(\mathrm{L}_{\max }\right)$, mortality rates $(\mathrm{M})$ and forcing variables; temperature $(\mathrm{T})$ and scaled functional response $(f)$, which ranges between 0 (no food) and 1 (maximum food) and is given by $f(X)=\frac{X}{X+K}$ where $\mathrm{K}$ is the half-saturation constant.

\begin{tabular}{|c|c|c|c|c|c|c|c|c|c|c|c|c|}
\hline & \multirow{2}{*}{$\begin{array}{l}\mathrm{L}_{\max } \\
(\mathrm{cm})\end{array}$} & \multirow{2}{*}{$\begin{array}{l}A_{\max } \\
\text { (d) }\end{array}$} & \multirow{2}{*}{$\begin{array}{c}M \\
\left(d^{-1}\right)\end{array}$} & \multicolumn{5}{|c|}{ Food $\left(\mathrm{mg} \mathrm{m}^{3}\right)$} & \multirow[b]{2}{*}{$f$} & \multicolumn{3}{|c|}{ Temperature ${ }^{\circ} \mathrm{C}$} \\
\hline & & & & $\mathrm{X}_{\text {mean }}$ & $a$ & $\omega$ & $K$ & Prey & & $\mathrm{T}_{\text {mean }}$ & $a$ & $\omega$ \\
\hline Yolk sac larvae & 0.37 & 4 & 0.63 & 0 & 0 & - & 0 & - & 0 & 18.5 & 4 & 237 \\
\hline Early larvae & 3.75 & 40 & 0.286 & 0.4 & 0.25 & 365 & 0.09 & Phyto & $0.65-0.85$ & 18 & 4 & 237 \\
\hline Late larvae & 5 & 80 & 0.057 & 0.4 & 0.25 & 360 & 0.09 & Phyto & $0.65-0.85$ & 17.5 & 4 & 237 \\
\hline Juveniles & 10.5 & 280 & 0.004 & 40 & 15 & 350 & 8.5 & SmlMeso & $0.6-0.8$ & 17 & 3 & 222 \\
\hline Adults & 15.8 & 1825 & 0.003 & 125 & 90 & 335 & 33 & Zoo & $0.45-0.9$ & 16 & 2 & 207 \\
\hline
\end{tabular}

*Given maximum ages $\left(\mathrm{A}_{\max }\right)$ are based on the standard $(\mathrm{GoL})$ model run. For larvae, prey consists of phytoplankton (Phyto) and was based on satellite derived sea surface chlorophyll-a concentrations; Juveniles fed on small mesoplankton (SmlMeso) sized $0.2-0.5 \mathrm{~mm}$ while adults fed on large mesoplankton consisting of zooplankton (Zoo) sized $>0.5 \mathrm{~mm}$ based on in situ measures taken during Costeau surveys. Mortality rates are taken from Pertierra et al. (1997) for the NW Mediterranean Sea with the exception of yolk-sac larvae values which were taken from $2007 \mathrm{GoL}$ field estimates (Palomera et al. 2007). $M=1$ at the end of age-4 (1825 days). For the forcing variables used in the models, sinusoidal functions were applied using the equation: $X(t)$ or $T(t)=\mathrm{X}_{\text {mean }}\left(\right.$ or $\left.\mathrm{T}_{\text {mean }}\right)+a \sin (2 \pi(\mathrm{t}+\omega) / 365)$, where $\mathrm{X}_{\text {mean }}$ or $T_{\text {mean }}$ is the

66 mean value, $a$ is the amplitude, and $\omega$ the phase shift of the sinusoid curve relative to the $1^{\text {st }}$ June, peak of the reproduction season. 
Table 4. Simulated feeding and growth rates under standard Gulf of Lion environmental conditions at various life-stages.

\begin{tabular}{|c|c|c|c|c|c|c|c|c|}
\hline \multirow[t]{2}{*}{ Life-stage } & \multirow{2}{*}{$\begin{array}{l}\text { Age } \\
\text { days }\end{array}$} & \multirow{2}{*}{$\begin{array}{l}\text { Weight } \\
\mathrm{g} \mathrm{W}_{\mathrm{ww}}\end{array}$} & \multirow{2}{*}{$\begin{array}{c}\text { Energy density } \\
\mathrm{J} \mathrm{g}^{-1} \mathrm{~W}_{\mathrm{ww}}\end{array}$} & \multicolumn{3}{|c|}{ Consumption rates } & \multicolumn{2}{|c|}{ Growth rates } \\
\hline & & & & $\mathrm{J} \mathrm{d}^{-1}$ & $\mathrm{~g} \mathrm{zOo}^{-1} \mathrm{~d}^{-1}$ & $\% \mathrm{BW} \mathrm{d}^{-1}$ & $\mathrm{~mm} \mathrm{~d}^{-1}$ & $m g W_{w w} d^{-1}$ \\
\hline Early larvae & 20 & 0.03 & 4927 & 36 & - & - & 0.84 & 3.5 \\
\hline Early larvae & 40 & 0.19 & 5370 & 162 & - & - & 0.80 & 14.1 \\
\hline Late larvae & 60 & 0.55 & 5550 & 304 & - & - & 0.64 & 21.9 \\
\hline Juveniles & 280 & 6.86 & 5748 & 691 & - & - & 0.14 & 32.0 \\
\hline Adults & & & & & & & & \\
\hline Age 1, Jul & 410 & 11.9 & 5809 & 1272 & 0.49 & 4.35 & 0.14 & 55.3 \\
\hline Age-2 Jul & 750 & 17.6 & 6020 & 1654 & 0.64 & 3.68 & 0.08 & 60.9 \\
\hline Oct & 850 & 18.2 & 5800 & 1381 & 0.53 & 2.98 & 0 & -10.9 \\
\hline Jan & 950 & 17.2 & 5720 & 1216 & 0.47 & 2.79 & 0 & 17.0 \\
\hline April & 1050 & 19.6 & 5910 & 1467 & 0.56 & 2.95 & 0.05 & 33.5 \\
\hline Age-3, Jul & 1150 & 22.5 & 6180 & 2018 & 0.78 & 3.55 & 0.04 & 71.3 \\
\hline Age-4, Jul & 1490 & 24.4 & 6140 & 2079 & 0.81 & 3.40 & 0.03 & 73.6 \\
\hline
\end{tabular}

Values are based on model predictions at a given age and thus, date in time. Estimated prey consumption and $\% \mathrm{BW}$ intake are missing in early life stages due to lack of prey density data. For calculations of adult weight related consumption rates, an energy density of $2580 \mathrm{~J} \mathrm{~g}^{-1}$ was used. Average growth weight rates do not include weight loss due to spawning events in which accounted for between 4 to $10 \%$ of total body weight.

Table 5. Description of the reproductive output (batch and egg fecundity) pattern as a function of its age for an individual hatched on the 1 June and grown under standard environmental conditions of the Gulf of Lion (Table 1 and Figure 2).

\begin{tabular}{cccc}
\hline & \# batches & \# eggs / batch & \# eggs / season \\
\hline Age 1 & 19 & $4500-8200$ & 133,270 \\
Age 2 & 23 & $7550-10500$ & 227,210 \\
Age 3 & 24 & $10300-12500$ & 273,400 \\
Age 4 & 23 & $11500-13600$ & 302,040 \\
\hline
\end{tabular}

81 
Appendix 1. Input growth data for the European anchovy in the Gulf of Lion (at a reference temperature of $16^{\circ} \mathrm{C}$ ) used to estimate DEB parameters using the simplex method (Lika et al. 2011) supplied in the freely available software, DEBtool (Kooijman et al. 2010).

\begin{tabular}{|c|c|c|c|c|}
\hline Variable & & Value & Unity & Reference \\
\hline $\begin{array}{l}\text { Length at birth (first } \\
\text { feeding) }\end{array}$ & $L_{b}$ & 0.36 & $\mathrm{~cm}$ & Ospina-Alvarez et al.2011 \\
\hline Length at puberty & $L_{p}$ & 10.5 & $\mathrm{~cm}$ & Roos unpublished data \\
\hline $\begin{array}{l}\text { Length maximum } \\
\text { (observed) }\end{array}$ & $L_{m}$ & 18.2 & $\mathrm{~cm}$ & Roos unpublished data \\
\hline Length ultimate $^{\wedge}$ & $L_{i}$ & 16.5 & $\mathrm{~cm}$ & Roos unpublished data \\
\hline Length at metamorphosis & $L_{j}$ & 3.75 & $\mathrm{~cm}$ & Mesa et al. 2011 \\
\hline Age at birth & $a_{b}$ & 4 & $\mathrm{~d}$ & Ospina-Alvarez et al. 2011 \\
\hline Age at puberty & $a_{p}$ & 320 & $d$ & Politikos et al 2011 \\
\hline $\begin{array}{l}\text { Life span maximum } \\
\text { (observed) }\end{array}$ & $a_{m}$ & 1825 & d & Roos unpublished data \\
\hline Weight at birth & $W_{b}$ & 0.031 & $\mathrm{~g} \mathrm{~W}_{\mathrm{ww}}$ & Palomera et al. \\
\hline Weight at puberty & $W_{P}$ & 12.7 & $\mathrm{~g} \mathrm{~W}_{\mathrm{ww}}$ & Roos unpublished data \\
\hline Weight at ultimate length ${ }^{\wedge}$ & $W_{i}$ & 36 & $\mathrm{~g} \mathrm{~W}_{\mathrm{ww}}$ & Roos unpublished data \\
\hline $\begin{array}{l}\text { Weight maximum } \\
\text { (observed) }\end{array}$ & $W_{m}$ & 40 & $\mathrm{~g} \mathrm{~W}_{\mathrm{ww}}$ & Roos unpublished data \\
\hline
\end{tabular}

